\title{
Dietary analysis of two sympatric marine turtle species in the eastern Mediterranean
}

\author{
Josie L. Palmer ${ }^{1}$ D $\cdot$ Damla Beton $^{2} \cdot$ Burak A. Çiçek $^{3,4} \cdot$ Sophie Davey $^{2} \cdot$ Emily M. Duncan $^{1} \cdot$ Wayne J. Fuller ${ }^{1,2,5}$. \\ Brendan J. Godley ${ }^{1}$. Julia C. Haywood ${ }^{1} \cdot$ Mehmet F. Hüseyinoğlu $^{6} \cdot$ Lucy C. M. Omeyer $^{1} \cdot$ M. Jesse Schneider ${ }^{1,7}$. \\ Robin T. E. Snape ${ }^{1,2} \cdot$ Annette C. Broderick ${ }^{1}$
}

Received: 3 November 2020 / Accepted: 23 April 2021 / Published online: 25 May 2021

(c) The Author(s) 2021

\begin{abstract}
Dietary studies provide key insights into threats and changes within ecosystems and subsequent impacts on focal species. Diet is particularly challenging to study within marine environments and therefore is often poorly understood. Here, we examined the diet of stranded and bycaught loggerhead (Caretta caretta) and green turtles (Chelonia mydas) in North Cyprus ( $35.33^{\circ} \mathrm{N}$, $33.47^{\circ} \mathrm{E}$ ) between 2011 and 2019. A total of 129 taxa were recorded in the diet of loggerhead turtles $(n=45)$, which were predominantly carnivorous (on average $72.1 \%$ of dietary biomass), foraging on a large variety of invertebrates, macroalgae, seagrasses and bony fish in low frequencies. Despite this opportunistic foraging strategy, one species was particularly dominant, the sponge Chondrosia reniformis (21.5\%). Consumption of this sponge decreased with increasing turtle size. A greater degree of herbivory was found in green turtles $(n=40)$ which predominantly consumed seagrasses and macroalgae $(88.8 \%)$ with a total of 101 taxa recorded. The most dominant species was a Lessepsian invasive seagrass, Halophila stipulacea $(31.1 \%)$. This is the highest percentage recorded for this species in green turtle diet in the Mediterranean thus far. With increasing turtle size, the percentage of seagrass consumed increased with a concomitant decrease in macroalgae. Seagrass was consumed year-round. Omnivory occurred in all green turtle size classes but reduced in larger turtles ( $>75 \mathrm{~cm}$ CCL) suggesting a slow ontogenetic dietary shift. Macroplastic ingestion was more common in green (31.6\% of individuals) than loggerhead turtles (5.7\%). This study provides the most complete dietary list for marine turtles in the eastern Mediterranean.
\end{abstract}

Responsible Editor: L. Avens.

Reviewers: Undisclosedexperts.

Josie L. Palmer

jlp231@exeter.ac.uk

1 Marine Turtle Research Group, Centre for Ecology and Conservation, University of Exeter, Penryn, UK

2 Society for Protection of Turtles, Levent Daire 1, Ulus Sokak, Gönyelli, North Cyprus

3 Underwater Research and Imaging Centre, Biological Sciences Department, Eastern Mediterranean University, 99628, Famagusta, North Cyprus

4 Department of Biological Sciences, Faculty of Arts and Sciences, Eastern Mediterranean University, 99628, Famagusta, North Cyprus

5 Faculty of Veterinary Medicine, Near East University, Nicosia, North Cyprus

6 Faculty of Maritime Studies, University of Kyrenia, Şehit Yahya Bakır Sokak, Karakum, Girne, North Cyprus

7 Abess Center for Ecosystem Science and Policy, University of Miami, Coral Gables, FL, USA

\section{Introduction}

Studies into the foraging ecology of marine organisms are logistically difficult due to the challenges of sampling animals in the marine environment (Newsome et al. 2010; Komoroske et al. 2017; Wildermann et al. 2018; Green et al. 2020). Recent technological advancements, such as satellite tracking and stable isotope analysis, have allowed elusive life stages to be studied over extended periods of time, providing valuable information, such as the location of foraging grounds, trophic level, and timing of ontogenetic dietary shifts (Cardona et al. 2010; Abascal et al. 2016; Haug et al. 2017; Andrews-Gof et al. 2018; Haywood et al. 2019, 2020a, b). Direct methods, such as gut content analysis (Bowen and Iverson 2013) or DNA meta-barcoding (Schwarz et al. 2018), enable a more detailed understanding of diet and account for variation within and among species and different demographics (Vander Zanden et al. 2010; Thomson et al. 2018), which can highlight differential threats among these groups. 
Although long-term conservation efforts have seen marine turtle populations begin to recover from historic declines (Mazaris et al. 2017), the majority are still impacted by numerous threats and their long-term persistence remains conservation-dependent (Casale et al. 2018). Interaction with fisheries is a leading cause of mortality of marine turtles worldwide (Lewison et al. 2014), and differing habitat use among demographic groups has been shown to influence susceptibility to some fishing techniques (Wallace et al. 2008; Casale 2011; Snape et al. 2013). Monitoring these responses to environmental change along with others, such as exposure to plastic ingestion (Duncan et al. 2019) and arrival and monitoring of invasive species (Özdilek et al. 2015), can be achieved through long-term dietary studies. Indeed, marine turtles are now used as bio-indicators for monitoring plastic pollution across the Mediterranean Sea through gut contents analysis (INDICIT Consortium 2018).

The Mediterranean basin is a critical region for green and loggerhead turtles, hosting one and two regional management units for each species, respectively (Wallace et al. 2011). Yet, it is one of the most understudied areas in relation to marine turtle diet, particularly for green turtles (Casale et al. 2018). Typically, marine turtles first have an obligate epipelagic-oceanic stage for 3 to 10 years (Reich et al. 2007; Casale et al. 2008; Lazar et al. 2008a), followed by a transitional stage where habitat shifts are facultative before recruiting to neritic habitats (Casale et al. 2008). Loggerhead turtles are widely considered opportunistic foragers (Bjorndal and Jackson 2003; Casale et al. 2008; Lazar et al. 2008a) with increasing prevalence of benthic prey with body size (Bjorndal 1997) due to improved diving capacity and buoyancy control (Musick and Limpus 1997) and increased bite force allowing access to harder prey items (Marshall et al. 2012). Green turtles are omnivorous foragers in their early life stages and thereafter tend to undergo an ontogenetic dietary shift to a predominantly herbivorous diet upon recruitment to neritic habitats (Reich et al. 2007; Arthur et al. 2008; Reisser et al. 2013; Stringell et al. 2013). However, recent research suggests levels of omnivory may be influenced by sea surface temperatures, where dietary animal matter features prominently in colder temperatures at higher latitudes $\left(<20^{\circ} \mathrm{C}\right.$ for $\geq 6$ months annually; Esteban et al. 2020) with the degree of omnivory varying spatially and seasonally by region.

Loggerhead turtle diet varies markedly across the Mediterranean Sea (Laurent and Lescure 1994; Godley et al. 1997; Tomás et al. 2001; Bentivegna et al. 2003; Lazar et al. 2008a) and includes fish, crustaceans, pelagic tunicates, molluscs, anemones and sea urchins (Tomás et al. 2001; Casale et al. 2008; Lazar et al. 2008a). Mediterranean green turtles have been reported to feed on the seagrass Cymodocea nodosa (Demetropoulus and Hadjichristophorou 1995; $n=3$ ), Posidonia oceanica and Zostera sp. (Durmuş 1998; $n=1)$ as well as Lessepsian invasives, namely the seagrass Halophila stipulacea, and the green algae Caulerpa taxifolia (Özdilek et al. 2015; $n=1$ ). These are just two of many hundreds of Lessepsian invasive species already recorded in the Mediterranean (Katsanevakis et al. 2014).

Stranding and bycatch records in the eastern Mediterranean demonstrate the presence of widespread neritic foraging grounds for both loggerhead and green turtles, predominantly for juveniles, around North Cyprus (Snape et al. 2013), Turkey (Başkale et al. 2018; Türkozan et al. 2018), Israel (Tikochinski et al. 2019), Egypt (Clusa et al. 2014) and Greece (Corsini-Foka et al. 2013). Although yearround strandings and bycatch occur in North Cyprus, the coastline also supports major nesting beaches used by both marine turtle species (Stokes et al. 2014; Casale et al. 2018), resulting in seasonal peaks of adult strandings and bycatch in summer months (Snape et al. 2013). Owing to ongoing engagement with collaborating small-scale fishers, much of the bycatch is reported directly through the Society for the Protection of Turtles (SPOT), providing opportunities to directly access diet of recently captured turtles, including highly understudied demographic groups. This study aimed to conduct a detailed gut contents analysis of marine turtles across North Cyprus to (1) quantify the relative contribution and variability of dietary taxa, (2) investigate dietary change with body size (CCL), (3) assess the prevalence of Lessepsian invasives within diet and (4) quantify macroplastic presence.

\section{Materials and Methods}

\section{Strandings, Bycatch Collection, and Necropsy}

From June 2011 to August 2019, 47 beaches across North Cyprus were monitored on foot for turtle strandings: every 1-3 days during the turtle nesting season (May-October) and monthly otherwise. Strandings were also reported by members of the public and bycaught turtles by local fishermen through a bycatch monitoring initiative. All bycaught turtles originated from within the EEZ of Cyprus. Livecaught turtles were immediately released if healthy; those that were already dead, or which died within $24 \mathrm{~h}$ of capture, and which received no feeding during rehabilitation were necropsied. Curved carapace length (CCL; notch-to-notch, Bolten 1999) was measured with a flexible tape measure as an indication of body size; where notch-to-notch measurements were not available, notch-to-tip measurements were converted using species-specific linear regressions calculated from nesting females and strandings between May and June 2018 (Supplementary Material S1). Body decomposition was assessed using a scale comprising the following categories: alive, fresh, partial decomposition, 
advanced decomposition, and mummified (INDICIT Consortium 2018); gut contents analysis was only conducted on individuals of fresh or partial body decomposition. Sex was ascertained by tail length (Casale et al. 2005) and gross morphology of the gonads (Lazar et al. 2008b).

\section{Gut Content Sample Collection and Analysis}

Gut contents of 46 loggerhead and 39 green turtles were collected and analysed. Gastrointestinal tracts were removed and separated into three sections: oesophagus, stomach and intestine. Identifiable dietary content and macroplastics (those visible to the naked eye) were removed from each section. Ingesta was then filtered through a $1 \mathrm{~mm}$ sieve using water and remaining contents were collected for identification. Unidentifiable items within the intestines that could not be separated were combined, weighed and percentage composition estimated (Supplementary Material S2). Dietary items were categorised into nine taxonomic groups: seagrass, macroalgae, sponge, cnidaria, other invertebrates, bony fish, unknown biological matter, macroplastic, and debris (only wood and sediment were identified). Dietary items were sorted and identified to the lowest taxonomic level possible within these taxonomic groups using a variety of reference materials as well as consultation with specialists. As some items could not be identified to the same level of accuracy, the term 'taxa' is used to refer to individual dietary items observed and encompasses items identified from phyla to species level throughout. Dietary items were blotted, and wet mass of each taxa was measured to the nearest $0.1 \mathrm{~g} ;<0.1 \mathrm{~g}$ was considered a trace amount. If present, macroplastics were cleaned, dried and dry mass recorded. This process was completed for all gastrointestinal sections.

Dietary composition was compared between the oesophagus, stomach, and intestines for samples collected between 2011 and 2018 to assess the inclusion of intestinal content in further analyses. No difference in dietary composition was found among sections (Supplementary Material S3). Due to the bias towards hard-bodied intestinal content and elevated digestion state precluding correct identification, the intestines were excluded from all analyses except the analysis of macroplastics ingestion with size, as they are often found in the largest quantities here (Matiddi et al. 2017) and persist in a non-degraded state (Clukey et al. 2017; Duncan et al. 2019). As no differences were found in dietary composition between gut sections, the oesophagus and stomach were subsequently combined for all further analyses. Reproductive status was not investigated due to the small sample size of adult-sized individuals in both turtle species.

Nine loggerhead and two green turtles had not been foraging prior to death; the oesophagus and stomach were either empty or contained low levels of solid anthropogenic waste only (Supplementary Material S4). These turtles were excluded from all dietary analyses as the cause for not foraging prior to death could not be established.

\section{Statistical Analyses}

All analyses were carried out in RStudio Desktop v. 3.6.3 (R Core Team 2020) and the significance level was alpha $=0.05$ throughout. For full details of statistical analyses and R-packages used, see Supplementary Material S5. While loggerhead and green turtles present markedly different size distributions, within species, most individuals are of a similar CCL, except for one small loggerhead turtle (Fig. 1a) and several large green turtles (Fig. 1b). To ensure these individuals did not bias models investigating the relationship of CCL with main dietary groups, $Z$-scores were calculated for all individuals to check for outliers in CCL. Only one loggerhead turtle had a Z-score of -4.88 exceeding the recommend threshold value of \pm 3 (Shiffler 1988) and was subsequently removed from all further analyses. Loggerhead and green turtles were analysed separately due to distinct differences in dietary composition and body size ranges. Sample accumulation curves were plotted for both turtle species (see Supplementary Material S5 and Fig. S5.1) to assess how representative dietary sampling was.

Dietary taxa biomass was standardised by total oesophagus and stomach content mass (mean relative percentage biomass) to account for differences in gastrointestinal fullness from turtles of varying body sizes. Frequency of occurrence (FO) was calculated as the percentage of individuals where a species or dietary group was present. Index of Relative Importance (IRI) values (von Brandis et al. 2014) were calculated as a combined measure of mean biomass and frequency of occurrence (Supplementary Material S5).

Ontogenetic dietary shifts were examined using CCL on a continuous scale throughout due to variability in size at sexual maturity across Mediterranean rookeries (Casale et al. 2018). Indications of nesting female sizes for North Cyprus are displayed in Fig. 1 for context.

\section{Results}

Of the 45 loggerhead turtles sampled, 21 were bycaught and 24 were strandings and of the 40 green turtles, 19 were bycaught and 21 were strandings. Of these, for loggerhead turtles, there were 20 females, 18 males and 7 of undetermined sex and, for green turtles, there were 18 females, 7 males and 15 of undetermined sex. Mean CCL was $X \pm \mathrm{SD}=63.4 \pm 9.3 \mathrm{~cm}$ for loggerhead turtles (range $18.8-82.3, n=44$, Fig. $1 \mathrm{a}$ ), and $X \pm \mathrm{SD}=38.5 \pm 17.1 \mathrm{~cm}$ for green turtles (range 26-89, $n=40$, Fig. 1b).

A combined total of 202 dietary taxa were recorded including 38 species and 15 families (Supplementary 
Fig. 1 Body size of study animals. Minimum curved carapace length $(\mathrm{cm})$ of stranded and bycaught (a) $\log$ gerhead $(n=44)$ and (b) green turtles $(n=40)$ sampled for gut contents in North Cyprus between 2011-2019, in $5 \mathrm{~cm}$ increments where for each category, individuals included are greater than or equal to the lower CCL boundary and less than the upper CCL boundary. Individuals found with macroplastic in their gastrointestinal tract are coloured dark grey. Dashed lines indicate the minimum (black) and mean (blue) nesting female size for Alagadi Beach, North Cyprus between 2011-2019; loggerhead (minimum: $59 \mathrm{~cm}$; mean: $X \pm \mathrm{SD}=71.8 \pm 4.0 \mathrm{~cm}$, $n=266)$ and green turtles (minimum: $73.3 \mathrm{~cm}$; mean: $X \pm \mathrm{SD}=87.5 \pm 5.7 \mathrm{~cm}, n=406)$

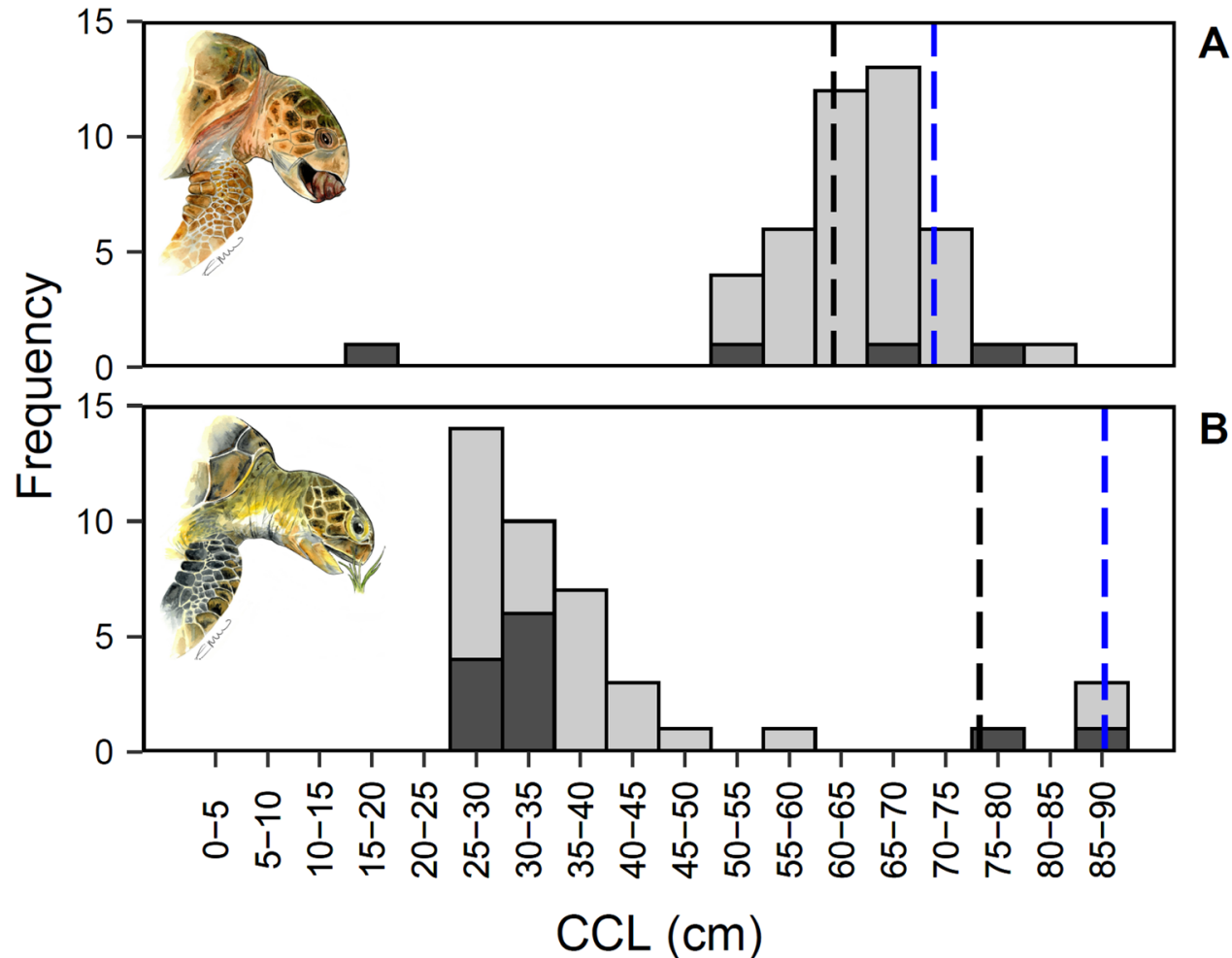

Material S6). Of the 38 species recorded, a total of 3 invasive species were identified, namely Halophila stipulacea, Caulerpa taxifolia and Caulerpa cylindracea which were found in both turtle species. There was little overlap in diet between marine turtle species where only 23 taxa were shared, including 12 species and 4 families. The diet of loggerhead turtles was more diverse with 129 different taxa observed compared to 101 taxa in green turtles. All dietary groups widely ranged in biomass in both turtle species, highlighting marked individual variation (Table 1), with the most diverse groups being macroalgae and miscellaneous invertebrates.

Dietary composition significantly differed between turtle species (ANOSIM, $R=0.410, n=73, p<0.001$; Fig. 2) which were $92.6 \%$ dissimilar. A SIMPER analysis showed that seagrasses, macroalgae, miscellaneous invertebrates and sponges contributed the most to these differences explaining $30.1 \%, 16.8 \%, 19.7 \%$ and $12.5 \%$ of the dissimilarity, respectively. No differences were found between sexes in either loggerhead (ANOSIM, $R=0.01, n=29, p=0.29$ ) or green turtles (ANOSIM, $R=-0.01, n=24, p=0.52$ ). There was also no difference found in dietary composition between stranded and bycaught turtles for either loggerhead (ANOSIM, $R=-0.03, n=35, p=0.86$ ) or green turtles (ANOSIM, $R=0.02, n=38, p=0.20)$ and therefore stranded and bycaught turtles were analysed collectively throughout the study.
Loggerhead turtles exhibited a higher ingestion of debris (4.6\% of biomass, predominantly wood) and omnivory (72.1\% animal matter, $7.9 \%$ plant matter, $15.4 \%$ of unknown origin, by biomass; Fig. 2a, b) than green turtles. The majority of dietary biomass consisted of invertebrates including sponges, cnidarians, crustaceans, molluscs, echinoderms (e.g., Holothuria sp.), polychaetes, and sea cucumbers (62.2\%). Piscivory was also observed in 5 individuals ranging from 58 to $72 \mathrm{~cm}$ CCL in size, 2 were stranded and 3 were bycaught, contributing $9.6 \%$ to dietary biomass on average. Most loggerhead dietary items had low contributions to relative biomass as well as low consumption frequencies; only two taxa had IRI scores $>1$, namely Chondrosia reniformis, a sponge, and the seagrass Posidonia oceanica with scores of 8 and 2, respectively. These also had the greatest contribution to overall biomass at $21.5 \%$ and $6.1 \%$, respectively. A species of migratory butterfly, the painted lady (Vanessa cardui), was also identified in one individual in trace amounts.

Green turtle diet was predominantly herbivorous $(88.8 \%$ plant matter, $9.8 \%$ animal matter, $1.3 \%$ of unknown origin by biomass; Fig. 2c, d), however evidence of omnivory, particularly in smaller size classes, was observed where bony fish were consumed $(5.0 \%)$, as well as miscellaneous invertebrates (2.4\%), such as Ligia italica, sponges $(2.2 \%)$ and cnidarians $(0.2 \%)$ (Table 1$)$. Bony fishes were found exclusively in stranded green turtles $(n=3)$, ranging in size from 32 to $57 \mathrm{~cm}$ CCL. Overall, seagrasses were the most 
Table 1 Dietary group composition of loggerhead $(n=35)$ and green turtles $(n=38)$ in North Cyprus

\begin{tabular}{|c|c|c|c|c|c|c|c|c|c|c|c|c|c|c|}
\hline \multirow[t]{3}{*}{ Dietary group } & \multicolumn{7}{|c|}{ Loggerhead turtle } & \multicolumn{7}{|c|}{ Green turtle } \\
\hline & \multirow[t]{2}{*}{ FO } & \multirow[t]{2}{*}{ IRI } & \multirow[t]{2}{*}{ Taxa } & \multicolumn{4}{|c|}{$\%$ of biomass } & \multirow[t]{2}{*}{ FO } & \multirow[t]{2}{*}{ IRI } & \multirow[t]{2}{*}{ Taxa } & \multicolumn{4}{|c|}{$\%$ of biomass } \\
\hline & & & & Mean & $\pm \mathrm{SE}$ & Min & $\operatorname{Max}$ & & & & Mean & $\pm \mathrm{SE}$ & Min & $\operatorname{Max}$ \\
\hline Seagrass & 45.7 & 2 & 3 & 6.5 & 3.8 & 0 & 98.4 & 92.1 & 73 & 5 & 57.4 & 6.8 & 0 & 100.0 \\
\hline Macroalgae $^{a}$ & 48.5 & $<1$ & 41 & 1.4 & 0.4 & 0 & 10.2 & 78.9 & 13 & 41 & 31.4 & 6.2 & 0 & 100.0 \\
\hline Sponge & 25.7 & 9 & 2 & 22.1 & 7.0 & 0 & 100.0 & 5.2 & $<1$ & 2 & 2.2 & 1.8 & 0 & 64.9 \\
\hline Cnidaria $^{\mathrm{b}}$ & 17.1 & $<1$ & 8 & 3.8 & 2.5 & 0 & 81.2 & 2.6 & $<1$ & 1 & 0.2 & 0.2 & 0 & 7.4 \\
\hline Other invertebrates ${ }^{c}$ & 74.3 & 23 & 47 & 36.3 & 7.4 & 0 & 100.0 & 65.8 & $<1$ & 39 & 2.4 & 1.6 & 0 & 50.0 \\
\hline Bony fish & 14.3 & 2 & 7 & 9.9 & 4.4 & 0 & 100.0 & 7.9 & $<1$ & 3 & 5.0 & 3.4 & 0 & 100.0 \\
\hline Unknown & 34.3 & 4 & 18 & 15.4 & 5.3 & 0 & 97.1 & 28.9 & $<1$ & 8 & 1.3 & 1.3 & 0 & 50.0 \\
\hline Debris & 17.1 & $<1$ & 2 & 4.6 & 3.0 & 0 & 98.8 & 10.5 & $<1$ & 1 & $*$ & $*$ & 0 & 0.8 \\
\hline Macroplastic & 5.7 & $<1$ & - & $*$ & $*$ & 0 & $*$ & 31.6 & $<1$ & - & 0.1 & $*$ & 0 & 0.8 \\
\hline
\end{tabular}

Percentage frequency of occurrence (FO), Index of Relative Importance (IRI), number of taxa (ranging from phylum to species level), mean relative percentage of biomass \pm SE, minimum and maximum values of dietary groups are shown (see Supplementary Table S3.1 for individual taxa summaries)

- NA values

*Values $<0.1$

${ }^{a}$ Chlorophyta, Ochrophyta, Rhodophyta

${ }^{\mathrm{b}}$ Anthozoa, gelatinous macroplankton

${ }^{\mathrm{c} C r u s t a c e a}$, Mollusca, Polychaeta, Holothuroidea, Echinodermata

dominant group, both collectively and individually, demonstrating both the highest percentage frequency of occurrence $(92.1 \%)$ and mean percentage contribution to biomass $(57.4 \%)$. A variety of macroalgae were consumed including $H$. scoparia and the invasive algae $C$. cylindracea, as well as Gelidium spinosum var hystrix being the most dominant $(8.7 \%, 8.2 \%$, and $6.3 \%$ of biomass, respectively). The seagrasses $H$. stipulacea and P. oceanica had both the highest contributions to overall biomass at $31.1 \%$ and $16.5 \%$, respectively, as well as the highest IRI scores of 29 and 10 . Only two other dietary species had IRI scores $>1$, the seagrass Zostera noltii and the green algae $C$. cylindracea both with scores of 2 (Supplementary Material S6). Green turtles also consumed terrestrial invertebrates with a grasshopper, a beetle and a black fly consumed in trace quantities $(0.4 \%,<0.1 \%,<0.1 \%$ of biomass, respectively), each observed once in 3 different turtles, but were not identified to species level.

Several breeding individuals were sampled across both study species, 3 loggerhead and 2 green turtles. Of these, 2 loggerhead turtles were female and 1 male with CCLs of $67 \mathrm{~cm}, 67.4 \mathrm{~cm}$, and $82.3 \mathrm{~cm}$, respectively, and both green turtles were female and were $86 \mathrm{~cm}$ and $89 \mathrm{~cm}$ CCL. All loggerhead turtles showed little evidence of foraging prior to death with on average $0.22 \pm 0.34 \mathrm{~g}$ (range $0.00-0.61 \mathrm{~g}$ ) of dietary content found. There was considerably more variation in the green turtles, with $1006 \mathrm{~g}$ and $281 \mathrm{~g}$ of dietary content found which predominantly consisted of seagrass (99.99\% and $39.5 \%)$ and macroalgae $(0.0 \%$ and $52.8 \%)$.
Generally, no clear seasonal or annual trends were observed in the main dietary groups of loggerhead (Fig. 3a, c) or green turtles (Fig. 3b, d) when considering percentage consumption. This was also true in the case of annual variation in both turtle species (Fig. 3c, d). The percentage of sponges consumed decreased in larger loggerhead turtles (GAM, $F=1.40, n=34 p=0.16$ ), whereas other invertebrates increased in larger-size classes (GAM, $F=3.69$, $n=34, p=0.03$; Fig. 3c; Supplementary Table S7.1). The percentage of seagrass consumption was greater in larger green turtles (GAM, $F=3.81, n=38, p=0.04$ ), whilst macroalgae decreased (GAMM, $F=2.18, n=38, p=0.08$; Fig. 3d) and bony fish consumption peaked in mid-size classes (GAMM, $F=5.19, n=38, p=0.02$; Supplementary Table S7.1).

As changes in percentages of one group may be confounded by another, the previous analyses were repeated using mass (g). Some seasonal variation is shown in all dietary groups across both turtle species (Supplementary Fig. S7.1A, B) with increases in the summer months. Mass of seagrass consumed in green turtles significantly increased with CCL (GAM, $F=170.72, n=38, p<0.001$ ) as did other invertebrates in loggerhead turtles (GAM, $F=13.82, n=34$, $p<0.001$; Supplementary Table S7.2; Supplementary Fig. S7.1).

As a dominant dietary item as well as an invasive species, $H$. stipulacea was examined separately in green turtles against month, year and CCL to identify any associations with certain life stages or temporal trends. No discernible 

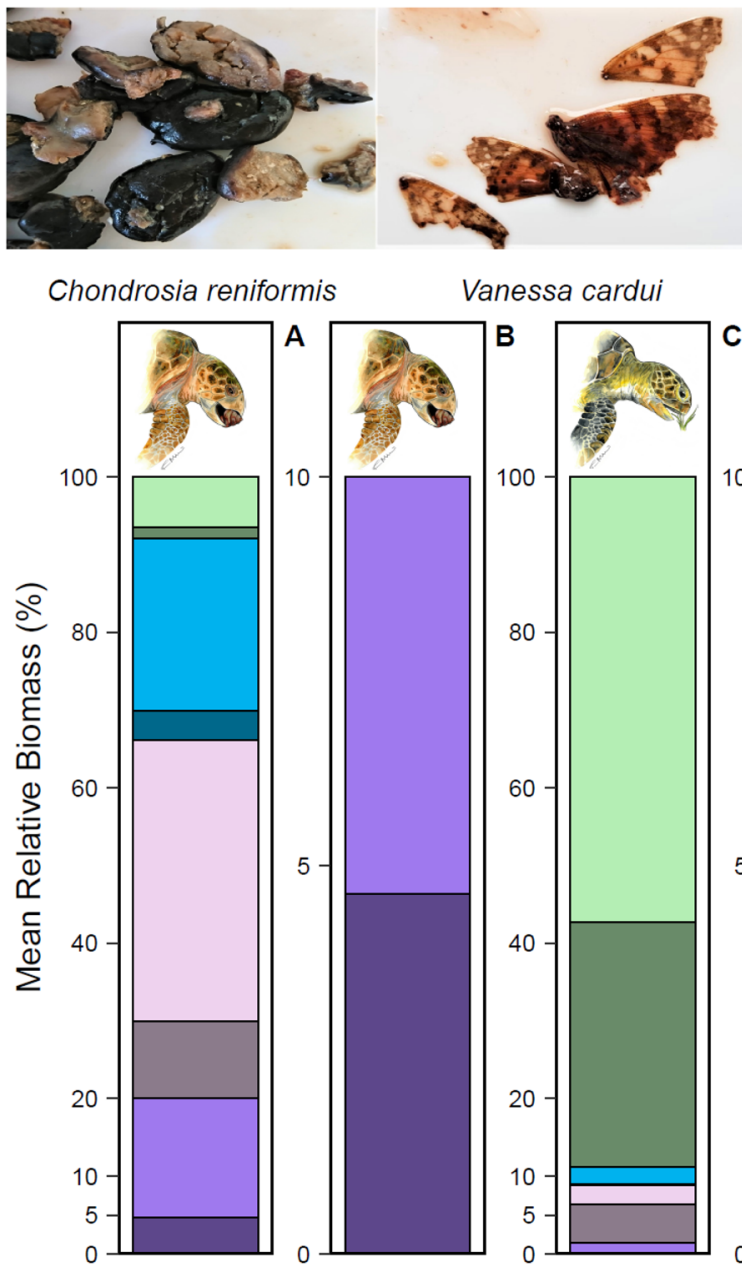

Vanessa cardui

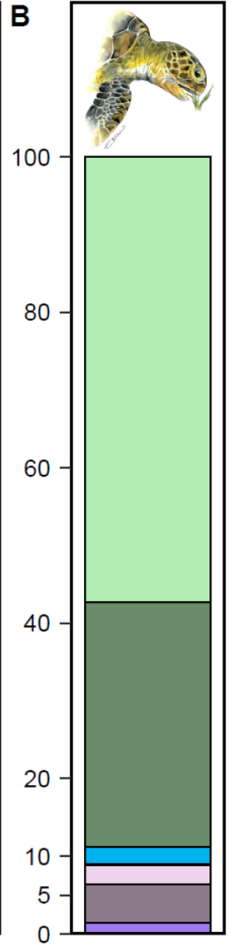

Fig. 2 Dietary composition of loggerhead and green turtles. Mean relative percentage contribution of each dietary group to biomass of each species is shown. For clarity, an enlargement of (a) loggerhead

patterns were observed with month with either percentage or mass of H. stipulacea consumed (Supplementary Fig. S7.2A, B). There was a decreasing annual trend when both percentage and mass were examined (Supplemental Fig. S7.2C, D). No effect was observed between CCL and percentage (GLM, $F=0.003, n=20, p=0.96$; Supplementary Fig. S7.2E) but there was a positive effect between CCL and mass (GLM, $F=35.80, n=20, p<0.001$; Supplementary Fig. S7.2F).

Neither species richness nor Simpsons Diversity Index of dietary content was influenced by CCL in loggerhead (GLM, $\chi^{2}{ }_{1}=0.66, n=34, p=0.42$, Fig. 4a; GLM, $F=0.90, n=34$, $p=0.35$; Fig. $4 \mathrm{c}$ ) or green turtles (GLM, $\chi^{2}{ }_{1}=1.58, n=38$, $p=0.21$, Fig. 4b; GLM, $F=0.09, n=38, p=0.76$; Fig. $4 \mathrm{~d}$ ).

Macroplastic ingestion was more common in green (31.6\%) than loggerhead turtles (5.7\%) and was also found in larger quantities, whilst accounting for differences due to $\mathrm{CCL}(X \pm \mathrm{SD}=0.72 \pm 2.21 \mathrm{~g}$, range: $0-12.3 \mathrm{~g}$, and

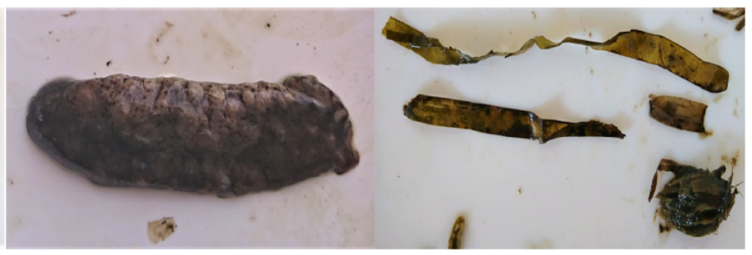

Holothuria sp.
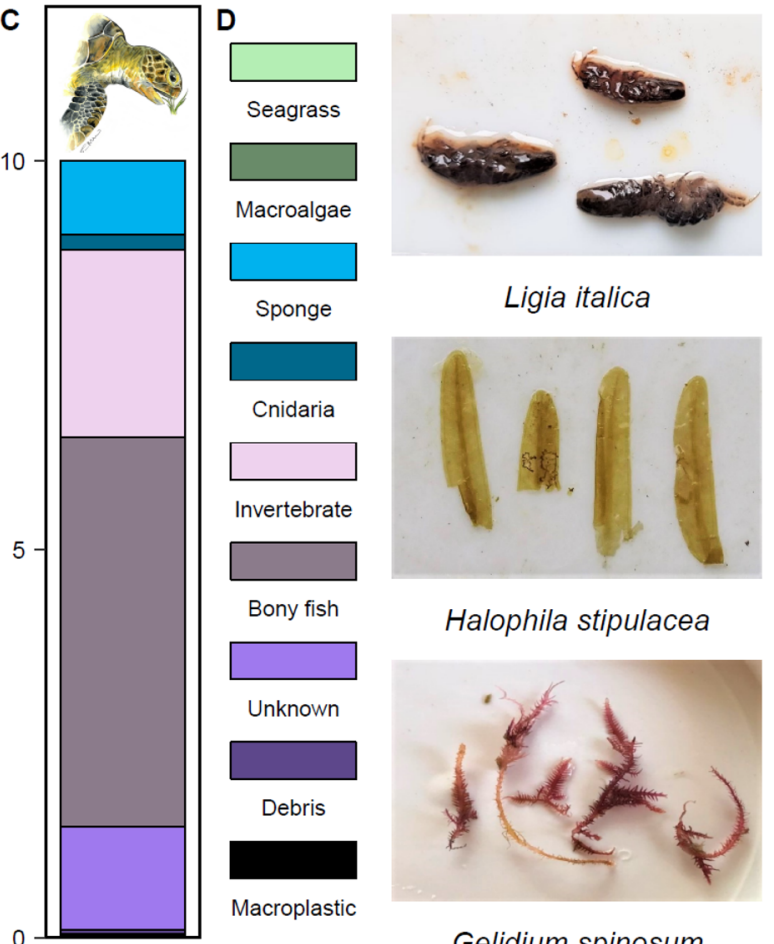

Ligia italica

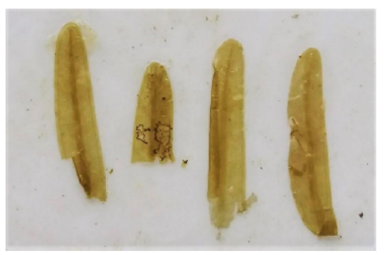

Halophila stipulacea

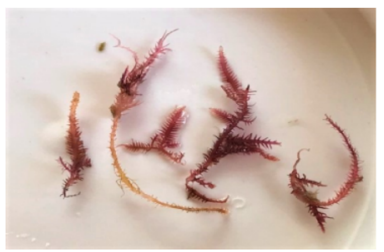

Gelidium spinosum

$(n=35)$ and (c) green turtles $(n=38)$ between $0-10 \%$ is shown in $(\mathbf{b})$ and (d), respectively. Images of main, and noteworthy dietary species are shown. Note the different $y$ axes scales

$\mathrm{X} \pm \mathrm{SD}=0.02 \pm 0.13 \mathrm{~g}$, range: $0-0.8 \mathrm{~g}$, respectively; GLM, $\mathrm{F}=14.88, n=73, p<0.001)$. Although a positive correlation was observed between plastic ingestion and cnidaria in loggerhead turtles $\left(R_{\mathrm{S}}=0.53, n=35, p=0.001\right.$; Supplementary Material S8), visual examination confirmed this relationship was unclear and centred around two individuals. All other taxonomic groups showed no correlations with plastic in either turtle species.

\section{Discussion}

This study provides the most detailed dietary information on marine turtles in the eastern Mediterranean thus far and is the first to compare the diet of the two sympatric species in the region. Dietary composition was significantly different between loggerhead and green turtles, confirming niche separation. A wide diversity of taxa were recorded 
including those that were unique to one and common to both species. High consumption of Lessepsian invasive species and a greater rate of plastic ingestion was shown in green turtles. Diet varied markedly from previous studies and other regions of the Mediterranean, highlighting the need for long-term local studies to monitor change and inform management.

\section{Loggerhead Turtle Diet}

Loggerhead turtles were found to have an omnivorous and more varied diet than green turtles, foraging on predominantly benthic items, such as the sponge Chondrosia reniformis and the bivalve Spondylus gaederopus, occurring from the surface down to $60 \mathrm{~m}$ (Bavestrello et al. 1996) and from 4 to $200 \mathrm{~m}$ depth (Demir 2003), respectively. Marked individual variation between loggerhead turtles was evident from low IRI scores. This supports the well-established theory of opportunistic foraging (Casale et al. 2008) and large isotopic niches found in regional stable isotope analysis (Haywood et al. 2020a). Studies in other regions of the Mediterranean Sea show some similarity, but the main constituent dietary groups vary (Laurent and Lescure 1994; Godley et al. 1997; Tomás et al. 2001; Bentivegna et al. 2003; Lazar et al. 2008a). Sponges and other invertebrates were dominant in the present study compared with crustaceans, gastropods and sea urchins in the central Mediterranean (Casale et al. 2008), sponges and sea urchins in the northern Adriatic (Lazar et al. 2002), and fish, pelagic tunicates, crustaceans, molluscs and other invertebrates in the western Mediterranean (Tomás et al. 2001). Percentage consumption of sponges consumed seemed to vary seasonally, decreasing between April-September, possibly driving the seasonal shifts in carbon stable isotope ratios found in this region (Haywood et al. 2020a). In the North Adriatic, percentage cover of $C$. reniformis is highest in autumn months and lowest in spring (Di Camillo et al. 2011) and although further north than the current study, supports seasonal abundance as an explanation of the peaks in sponge consumption observed here.

Sponges, and more specifically $C$. reniformis, have previously been identified as a major component of loggerhead turtle diet in the Mediterranean but were similarly found in an undigested state throughout the gut (Steuer 1905; Laurent and Lescure 1994; Lazar et al. 2002; Casale et al. 2008). Loggerhead turtle stomach morphology differs to that of hawksbill turtles, a well-known sponge specialist (Meylan 1988; Stringell et al. 2016), and it has been suggested that they are unlikely to obtain much nutrition from sponges, likely obtaining bacterial fauna or trace elements instead (Laurent and Lescure 1994; Casale et al. 2008). Similarly, Posidonia oceanica was another dominant species found in loggerhead turtle gut contents. Whilst P. oceanica beds are clearly frequented, its presence in their gut contents does not necessarily indicate that it is a dietary item. The gut microbiome of loggerhead turtles does contain anaerobic bacteria capable of fermenting carbohydrates (Arizza et al. 2019), such as Ruminococcacea and Lachnospiracea (Boutard et al. 2014) which are also found within green turtle guts (Ahasan et al. 2018; Campos et al. 2018). However, digestibility of structural carbohydrates in loggerhead turtles is largely unknown requiring further experimental work to clarify. Considering the undigested state of $P$. oceanica in the present study as well as in others (Casale et al. 2008), alternative explanations for its presence such as incidental ingestion while feeding on other animal prey species are more likely.

\section{Green Turtle Diet}

Green turtles were predominantly herbivorous where a greater incidence of omnivory was observed in juvenilessome had solely fed on animal matter-which shifted to near exclusive herbivory in adults as has been previously shown in the Mediterranean (Özdilek and Aureggi 2006; Lazar et al. 2010; Karaa et al. 2012). Throughout all-size classes, green turtles exhibited higher levels of herbivory than loggerhead turtles. Seagrass consumption was consistent throughout the year suggesting year-round dependence with potential seasonal peaks during summer months. The highest percentage cover and above-ground biomass of $\mathrm{Hal}$ ophila stipulacea, occurs in autumn around Cyprus (Nguyen et al. 2020) which coincides with a summer peak.

Dietary preferences of green turtles are known to vary regionally, with some populations specialising on seagrasses (Howell et al. 2016; Stringell et al. 2016; Gillis et al. 2018) and others on various macroalgae phyla (Carrión-Cortez et al. 2010; Reisser et al. 2013; Vélez-Rubio et al. 2016). Some of this variation can be attributed to differences in digestibility of dietary groups, where red algae have recently been shown to have higher digestibility than brown algae or seagrasses (Campos and Cardona 2020). Despite a preference for the seagrass Cymodocea nodosa noted previously around Cyprus (Demetropoulos and Hadjichristophorou 1995; Margaritoulis and Teneketzis 2003; Teneketzis et al. 2006; Casale et al. 2018), the Lessepsian seagrass H. stipulace $a$ and native $P$. oceanica were the most dominant in the present study. The nutritional quality of $C$. nodosa has been demonstrated to exceed that of $P$. oceanica in dietary preference studies of other Mediterranean herbivores, through both the higher quality of its leaves as well as its epiphytic community (Marco-Méndez et al. 2015). Considering $C$. nodosa was generally not a preferred dietary species in the current study and with $H$. stipulacea (Beca-Carretero et al. 2020) and $P$. oceanica (Telesca et al. 2015) both widespread off Cyprus, this may suggest they are more prevalent than $C$. 
Fig. 3 Temporal and sizerelated patterns in dominant dietary groups. Influence of month, year and CCL on other invertebrates (light blue) and sponges (dark blue) in (a, c, e) loggerhead $(n=34)$ and seagrasses (light green) and macroalgae (dark green) in $(\mathbf{b}, \mathbf{d}, \mathbf{f})$ green turtles $(n=38)$. Solid lines represent mean relative biomass percentage response and shaded region represents $\pm 1 \mathrm{SE}$. Note different $x$-axis scales in $(\mathbf{e}, \mathbf{f})$
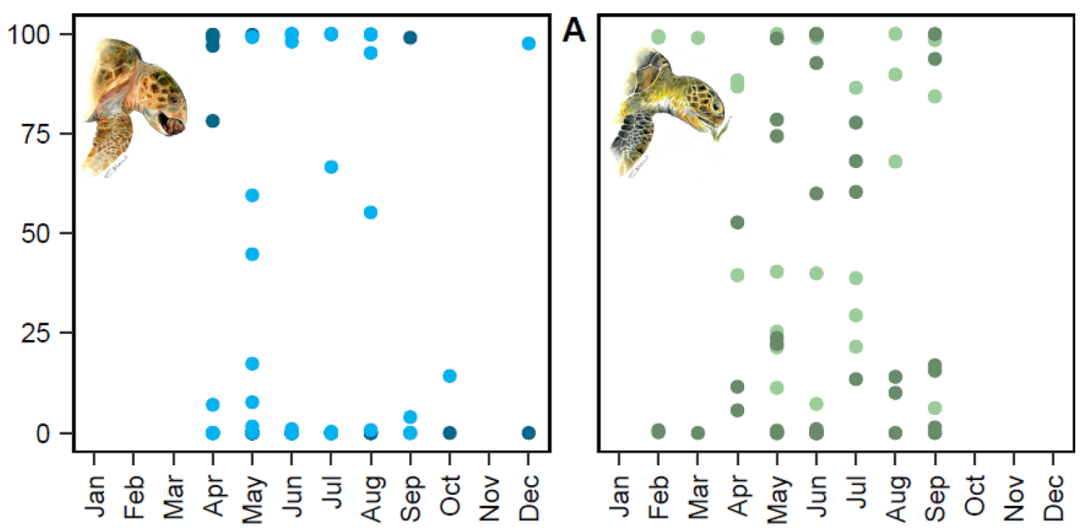

B

Month
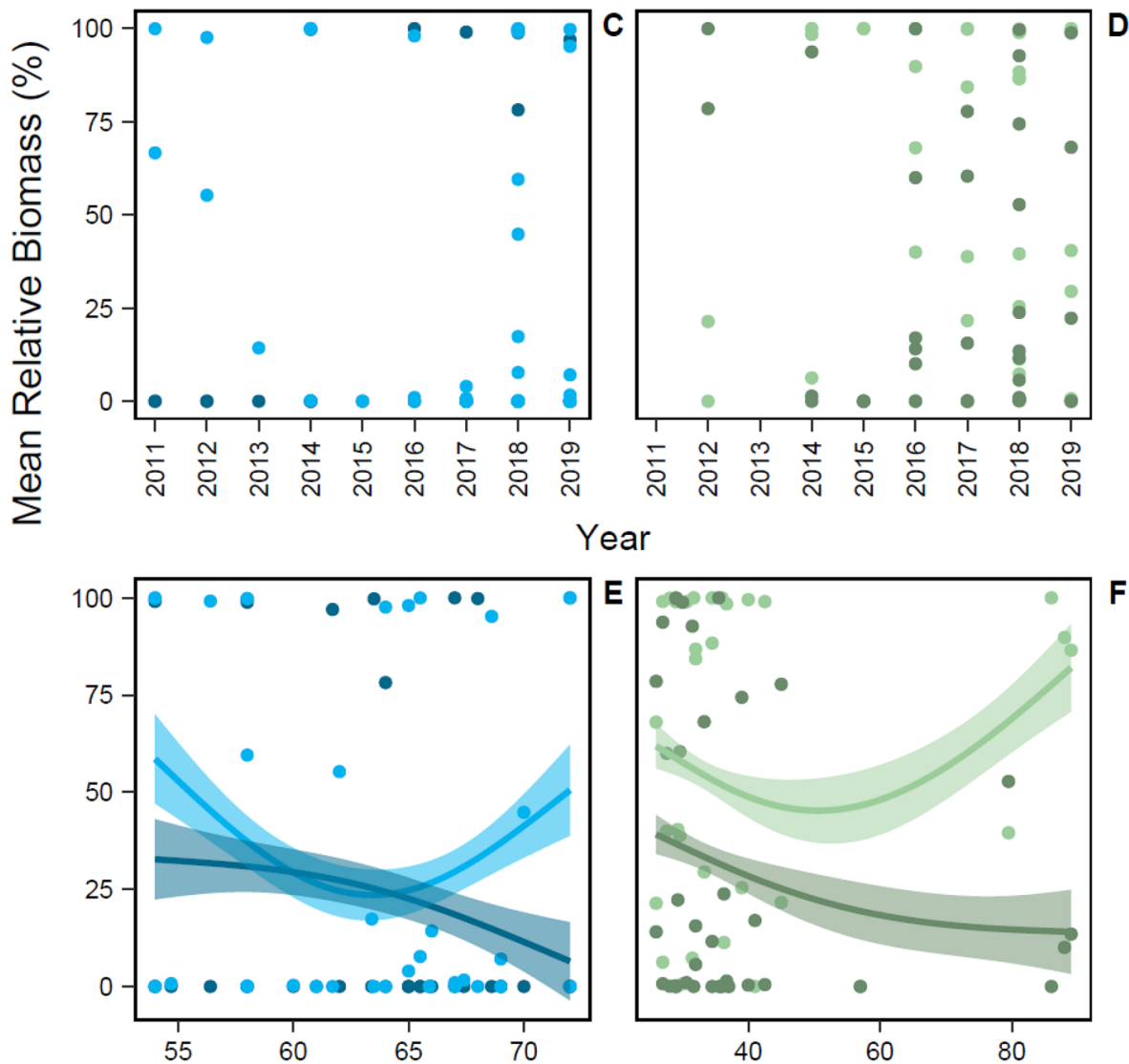

$\mathrm{CCL}(\mathrm{cm})$ nodosa, with prey availability driving dietary preferences. This is consistent with other studies noting local availability of resources as a key determining factor (Cardona et al. 2010; Reisser et al. 2013; Campos and Cardona 2020) where some green turtles primarily consume macroalgae instead in regions where seagrasses are scarce (e.g., Carrión-Cortez et al. 2010; Reisser et al. 2013; Vélez-Rubio et al. 2016).

Halophila stipulacea is a native dietary component for green turtles in the Indo-Pacific (Spalding et al. 2003) but is not always preferred when present in a seagrass assemblage; greater prevalence of three other seagrass species (Thalassodendron ciliatum, Thalassia hemprichii and Halodule uninervis) have been reported previously (Stokes et al. 2019). This is also the case in some regions where H. stipulace $a$ has invaded, such as the Caribbean, where green turtles have retained preferences for native seagrass species which also have better nutritional quality than $H$. stipulacea (Christianen et al. 2018). Concerns over this species rapidly invading and altering existing seagrass meadows have been raised (Sghaier et al. 2014; Nguyen et al. 2020), with 
ongoing tropicalisation of the Mediterranean increasingly favouring growth of $H$. stipulacea (Gambi et al. 2009; Jordà et al. 2012; Georgiou et al. 2016). Indeed, this study documents the highest percentage of $H$. stipulacea in green turtle diet thus far in the Mediterranean Sea. Rhizomes and roots of $H$. stipulacea were found in green turtle gut contents, possibly indicating utilisation of a previously documented below-ground foraging strategy (Christianen et al. 2014), that may act as a natural biocontrol (Whitman et al. 2019), as the majority of biomass is stored below-ground in H. stipulacea beds around Cyprus (Nguyen et al. 2020).

Consumption of $H$. stipulacea generally decreased between 2012 and 2019 but this could be due to increased sampling effort in later years providing a more accurate reflection of consumption levels. Further speculation of this trend is limited as the locations and the extent of seagrass beds remain poorly explored around Cyprus. Many studies on H. stipulacea around Cyprus have been conducted primarily along the south coast (Lipkin 1975; Nguyen et al. 2018; Winters et al. 2020 and references therein) with only a basic indication of their locations in North Cyprus (Georgiou et al. 2016). Recent evidence suggests it is widespread along the entirety of the Cyprus coastline (Beca-Carretero et al. 2020) but precise mapping of location of beds, extent and incorporation into native seagrass meadows in this region is lacking. Further speculation of the trend in consumption of $H$. stipulacea in the present study is therefore limited, and merits further sampling of not only stomach contents, but also systematic habitat surveys to map the locations of $H$. stipulacea and native seagrass beds to provide baselines with which to compare its spread and provide context for observed consumption rates and dietary preferences in marine turtles.

\section{Interactions With Fisheries}

Despite differences in foraging strategies, evidence of bony fish consumption was found in stomach contents of both marine turtle species. These may have occurred through depredation in bottom-set nets in which most turtles were thought to have drowned, since spoiling of catch by turtles is a common complaint of fishers (Snape et al. 2013). It is also possible that some turtles are feeding on fisheries discards as provisioning of some turtles in the harbours of North Cyprus has been noted (pers obs).

Fishing intensity and techniques vary greatly across the Mediterranean (Casale 2011) and will differentially affect turtle species depending on their foraging ecology and habitat use (Haywood et al. 2020a). Bycatch of loggerhead turtles around North Cyprus has been more closely linked to demersal gears used in deeper water fishing techniques, whereas green turtle interactions are typically with shallow water fishing gear (Snape et al. 2013). No sex-specific differences were observed in the current study suggesting similar foraging strategies and susceptibility to fishing pressures which is also evident from a high overlap in isotopic niche between sexes (Haywood et al. 2020a). However, dietary differences with reproductive status do occur elsewhere (Stokes et al. 2019) and preliminary evidence from the current study, particularly in the case of breeding loggerhead turtles which had foraged very little, suggests this may also occur in North Cyprus, but this requires further sampling to confirm.

\section{Terrestrial Dietary Content}

Cyprus is a known hotspot for migrating insects (John et al. 2015; Sparrow et al. 2016; Flint 2019) and therefore it is likely many insects die whilst flying over water. These dead insects may accumulate on the water's surface resulting in an easily accessible food resource for marine turtles. Indeed, both marine turtle species consumed terrestrial insects, such as butterflies, flies, beetles and grasshoppers, but only in trace amounts. This has been demonstrated previously in low quantities but mostly in young oceanic-pelagic posthatchling marine turtles (Richardson and McGillivary 1991; Witherington 2002; Witherington et al. 2012; McDermid et al. 2018). Very few records exist of marine turtles that are not post-hatchlings consuming terrestrial insects (Godley et al. 1998), this study included.

\section{Dietary Changes With Body Size}

An increase in benthic prey species is often reported as marine turtles increase in size (Salmon et al. 2004; Casale et al. 2008; Marshall et al. 2012). In general, no marked changes occurred in benthic material as loggerhead turtles increased in size here, but this is likely due to the restricted size range and lack of small individuals in this study. Percentage sponge consumption decreased with increasing loggerhead turtle size, suggesting a greater role in smaller turtles as suggested previously in the Mediterranean (Laurent and Lescure 1994). The decrease in the observed sponge consumption coincided with a small increase in the consumption of other invertebrates suggesting replacement of sponges with other invertebrates. Macroalgae consumption decreased in larger green turtles in favour of seagrass. However, this decrease is a result of a relative increase in the mass of seagrass consumed. Total biomass consumed inevitably scales with body size, and whilst mass is useful for highlighting relative changes in groups' biomass, it does not account for differences in stomach size and fullness as percentage biomass does and should therefore be viewed as supplementary to this. Although diet was predominantly herbivorous, omnivory was observed in a range of size classes providing further evidence to previous stable 
Fig. 4 Size-related diversity in diet. Species richness (purple) and Simpson's Diversity Index (grey) of stomach content samples against curved carapace length (CCL) for $(\mathbf{a}, \mathbf{c})$ loggerhead $(n=34 ; p=0.42 ; p=0.35)$ and $(\mathbf{b}, \mathbf{d})$ green turtles $(n=38$; $p=0.21 ; p=0.76$ )
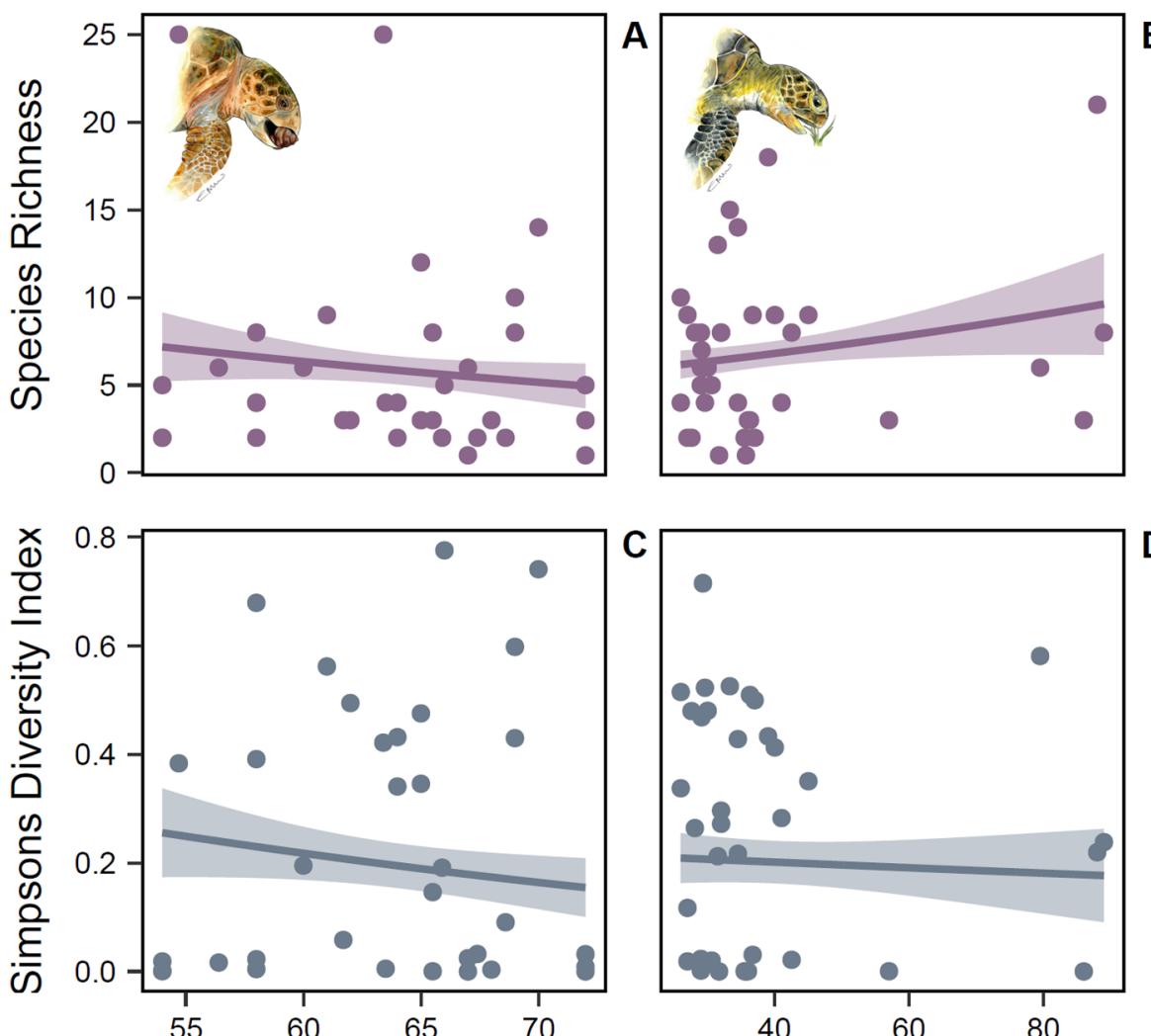

$\mathrm{CCL}(\mathrm{cm})$ isotope analyses of a slow ontogenetic dietary shift in the eastern Mediterranean basin (Godley et al. 1998; Cardona et al. 2010).

\section{Recruitment Size}

Small juvenile green turtles and large juvenile loggerhead turtles were the most common life stages in this study, most frequently observed between 25 and $30 \mathrm{~cm}$ and 60 and $70 \mathrm{~cm}$ CCL, respectively. Loggerhead turtles can recruit to neritic waters very early in the Mediterranean (Lazar et al. 2007; Abbate et al. 2007) from as small as $25 \mathrm{~cm}$ CCL (Casale et al. 2008) but this can be highly variable due to their relaxed life history (Casale et al. 2007). In this study however, few loggerhead turtles of this size were recorded, suggesting neritic recruitment occurs later around Cyprus, at around 50-65 cm CCL. Globally, green turtles recruit to neritic foraging grounds around $25-44 \mathrm{~cm} \mathrm{CCL}$ (Reich et al. 2007; Arthur et al. 2008) at approximately 3-10 years of age (Reich et al. 2007; Casale et al. 2008; Lazar et al. 2008a). Our results are consistent with this, with green turtles recruiting at a minimum size of $25-30 \mathrm{~cm}$ CCL.

\section{Uncommon Size Classes}

The stark absence of mid-size green turtles in the current study could be a result of heavy fisheries bycatch mortality limiting survival. If this is the case, then this is of great concern, and could represent a wider problem in the region. Alternatively, the observed absence of mid-size green turtles could reflect developmental transience as has been found in other populations (Hamabata et al. 2015). Small juveniles may recruit to neritic developmental grounds, to later migrate to other coastlines as mid-size juveniles for the final stages of development prior to adulthood such as the wellknown adult foraging grounds off the coasts of North Africa and Turkey (Stokes et al. 2015). Mixed stock analyses in the eastern Mediterranean have shown up to $62 \%$ of loggerhead turtle strandings in the western foraging area of Turkey originate from Cyprus (Türkozan et al. 2018) as well as green turtles stranding on the Israeli coast, albeit a comparatively lower contribution of turtles originated from Cyprus in this case (Tikochinski et al. 2018). Conversely, post-nesting movements of some adult green turtles tracked from Cyprus nesting beaches highlighted foraging grounds in southern Cyprus and north in Turkey (Stokes et al. 2015; unpubl data), indicating that conditions can support development 
to adulthood in these areas. To better understand the parameters shaping population structures, mark recapture studies in coastal fisheries could be supported.

\section{Non-Foraging Turtles}

A small number of turtles in this study exhibited empty oesophagi and stomachs, indicating potential underlying health conditions. Where empty gastrointestinal tracts have been noted previously, cold-stunning was identified as the stranding cause (Burke et al. 1994; Bean and Logan 2019) which precludes normal foraging activity. No evidence of cold-stunning was found in this study, but many loggerhead turtles and some green turtles were of adult size, with several identified as breeding individuals, and were recorded between March and July. This may suggest they were migrant breeders as nesting occurs between May and October (Broderick et al. 2002). Specifically, for females, foraging could be limited due to egg maturation processes (Bjorndal 1997).

\section{Macroplastic Ingestion}

Green turtles demonstrated greater macroplastic ingestion than loggerhead turtles, a similar finding to other studies (Parker et al. 2011; Schuyler et al. 2013; Clukey et al. 2017; Rizzi et al. 2019). This is likely related to diet, where herbivores and gelatinovores are more likely to ingest anthropogenic debris, including plastic, than carnivores (Schuyler et al. 2013; Di Beneditto and Awabdi 2014; Rizzi et al. 2019). The incidence of plastic ingestion of green turtles was much lower than in previous studies; 12 of 38 green turtles $(31.6 \%)$ in the current study had ingested plastic compared with $100 \%$ of 19 turtles sampled in a previous study in the same region (Duncan et al. 2019). Both studies included the whole gut in analyses, so this difference may instead be due to a larger sample size and extended sampling period in the present compared to the previous study (2011-2019 and 2014-2016, respectively). Other confounding factors such as the potential for lower plastic pollution levels in more recent years should also be considered.

The percentage of ingested macroplastics did not vary with turtle size in either species. This may be due to the sizes of turtles sampled; the present study examined loggerhead turtles between 54.0 and $72.0 \mathrm{~cm}$ CCL representing a limited number of life stages, and an overall larger sample size of green turtles with greater inclusion of larger individuals than previous studies (e.g., Duncan et al. 2019). Locally available prey resources in addition to environmental plastic levels may influence the types and quantities of plastic ingested in different areas and life stages. Recording baseline measures of environmental plastics present in North Cyprus marine turtle foraging habitats would allow further comparison of plastic types that prevail in gut contents with their availability in the environment.

\section{Concluding Statements}

The diet of loggerhead and green turtles in the eastern Mediterranean largely aligned with previous research in both the Mediterranean and globally, but regional differences in the main dietary groups were evident, reinforcing the need for specific regional management of these species and their supporting habitats. Distinct niche separation was evident and is likely to increase susceptibility to differing threats, such as deeper, demersal fishing practices and shallow water fishing efforts, for loggerhead and green turtles, respectively (Snape et al. 2013). Sponges, whilst not a novel dietary item in the diet of loggerhead turtles in the Mediterranean (Steuer 1905; Laurent and Lescure 1994; Lazar et al. 2002; Casale et al. 2008), are relatively uncommon and their dietary role is still largely unknown. As sponges were so prevalent in a predominantly opportunistic forager that generally does not show digestive capability for such taxa, a better understanding of the nutritional and functional role of sponges would provide key insights into loggerhead turtle foraging behaviour, ontogenetic dietary changes, and nutritional requirements. An invasive seagrass, $H$. stipula$c e a$, was recorded in the highest levels for green turtles thus far in the Mediterranean, as well as outside its native ranges. Globally, studies have highlighted $H$. stipulacea's role in rapid displacement of native seagrass meadows (Willette and Ambrose 2012; Smulders et al. 2017; Winters et al. 2020 and references therein), green turtle's continued preference for native seagrass species and its lower nutritional value in some cases (Christianen et al. 2018). With H. stipulacea clearly already a major dietary component in the eastern Mediterranean, and few examples of consumption of this invasive species outside its normal range, further research into the location of $H$. stipulacea beds around Cyprus, its nutritional value relative to native Mediterranean seagrasses and the impacts of a $H$. stipulacea rich diet on green turtles is imperative. To augment the preliminary findings of the current study, a more detailed analysis of habitat utilisation and identification of foraging ground locations is suggested to better define dietary preferences relative to local resource availability, possible habitat and dietary species shifts with climate change and invasive species, and overlap of foraging grounds with fisheries to implement effective marine protected areas and modifying existing fishing practices for marine turtles in the eastern Mediterranean.

Supplementary Information The online version contains supplementary material available at https://doi.org/10.1007/s00227-021-03895-y. 
Acknowledgements We thank all volunteers and fishers of the Marine Turtle Conservation Project, a collaboration between the Marine Turtle Research Group, the North Cyprus Department for Environmental Protection, the North Cyprus Department for Animal Husbandry and the North Cyprus Society for the Protection of Turtles (SPOT). Thanks to Silem Sargın and Sude Çelik and Meritta Sea Turtle Rehabilitation Centre. Thanks to Sandra Hochscheid and her colleagues at the Stazione Zoologica Anton Dohrn in Naples, Italy for their specialist expertise and advice in species identification. Original artwork illustrations were designed and produced by Emma Wood. We thank the 3 anonymous reviewers and the editor, whose inputs have greatly improved the manuscript.

Authors' contribution RTES, BJG and ACB conceived the study and acquired the necessary funding; JLP, DB, SD, EMD, WJF, JCH, LCMO, MJS and RTES conducted fieldwork and necropsies. MFH assisted with identifications of dietary species. DB, SD, RTES, BAC, LCMO, EMD and JLP coordinated fieldwork logistics. JLP assembled and analysed data, produced all figures, and was lead author on the manuscript. EMD, BJG, JCH and ACB provided guidance on data analysis and writing, and all co-authors read, provided useful comments and approved the final manuscript.

Funding This research was funded and supported by Erwin Warth Foundation, Karşıyaka Turtle Watch, Angela Wadsworth, Maureen and Tony Hutchinson, Kuzey Kibris Turkcell, MAVA Foundation, Natural Environment Research Council and the University of Exeter. EMD and BJD are supported by European Commission project INDICIT II (11.0661/2018/794561/SUB/ENV.C2).

Data/Code availability Data and any available visuals, such as figures and tables, will be provided upon reasonable request to the corresponding author. Any codes created to assist in data analysis and/or any software application utilised in the current study will be provided upon reasonable request submitted to the corresponding author.

\section{Declarations}

Conflict of interest The authors declare that they have no conflicts of or competing interests associated with this project or manuscript preparation.

Ethical approval All field work and necropsies were conducted under permits granted to SPOT by the Department for Environmental Protection and the Department for Animal Husbandry. Approval was also obtained from the ethics committee of the University of Exeter; approval number 2018/2351.

Informed consent Consent for participation is not applicable to this study as there were no human test subjects.

Open Access This article is licensed under a Creative Commons Attribution 4.0 International License, which permits use, sharing, adaptation, distribution and reproduction in any medium or format, as long as you give appropriate credit to the original author(s) and the source, provide a link to the Creative Commons licence, and indicate if changes were made. The images or other third party material in this article are included in the article's Creative Commons licence, unless indicated otherwise in a credit line to the material. If material is not included in the article's Creative Commons licence and your intended use is not permitted by statutory regulation or exceeds the permitted use, you will need to obtain permission directly from the copyright holder. To view a copy of this licence, visit http://creativecommons.org/licenses/by/4.0/.

\section{References}

Abascal FJ, Medina A, De La Serna JM, Godoy D, Aranda G (2016) Tracking bluefin tuna reproductive migration into the Mediterranean Sea with electronic pop-up satellite archival tags using two tagging procedures. Fish Oceanogr 25:54-66. https://doi. org/10.1111/fog. 12134

Abbate G, Casale P, Freggi D, Rocco M, Argano R (2007) Diet and ecological transition of loggerhead sea turtles (Caretta caretta) in the central Mediterranean. In: Frick M, Panagopoulou A, Rees AF, Williams K (eds) Book of abstracts, 27th annual symposium on sea turtle biology and conservation. IUCN, Miami

Ahasan MS, Waltzek TB, Huerlimann R, Ariel E (2018) Comparative analysis of gut bacterial communities of green turtles (Chelonia mydas) pre-hospitalization and post-rehabilitation by highthroughput sequencing of bacterial 16S rRNA gene. Microbiol Res 207:91-99. https://doi.org/10.1016/j.micres.2017.11.010

Andrews-Gof V, Bestley S, Gales NJ, Laverick SM, Paton D, Polanowski AM, Schmitt NT, Double MC (2018) Humpback whale migrations to Antarctic summer foraging grounds through the southwest Pacific Ocean. Sci Rep 8:12333. https://doi.org/10. 1038/s41598-018-30748-4

Arizza V, Vecchioni L, Caracappa S, Sciurba G, Berlinghieri F, Gentile A, Persichetti MF, Arculeo M, Alduina R (2019) New insights into the gut microbiome in loggerhead sea turtles Carretta carretta stranded on the Mediterranean coast. PLoS ONE 14:e0220329. https://doi.org/10.1371/journal.pone.0220329

Arthur KE, Boyle MC, Limpus CJ (2008) Ontogenetic changes in diet and habitat use in green sea turtle (Chelonia mydas) life history. Mar Ecol Prog Ser 362:303-311. https://doi.org/10.3354/meps0 7440

Başkale E, Sözbilen D, Katılmış Y, Azmaz M, Kaska Y (2018) An evaluation of sea turtle strandings in the Fethiye-Göcek specially protected area: an important foraging ground with an increasing mortality rate. Ocean Coast Manag 154:26-33. https://doi.org/ 10.1016/j.ocecoaman.2018.01.003

Bavestrello G, Cerrano C, Cattaneo-Vietti R, Sara M, Calabria F, Cortesogno L (1996) Selective incorporation of foreign material in Chondrosia reniformis (Porifera, Demospongiae). Ital J Zool 63:215-220. https://doi.org/10.1080/11250009609356136

Bean SB, Logan JM (2019) Stable isotope analyses of cold-stunned Kemp's ridley (Lepidochelys kempii) sea turtles at the northern extent of their coastal range. Mar Biol 166:64. https://doi.org/10. 1007/s00227-019-3516-2

Beca-Carretero P, Teichberg M, Winters G, Procaccini G, Reuter H (2020) Projected rapid habitat expansion of tropical seagrass species in the Mediterranean Sea as climate change progresses. Front Plant Sci 11:555376. https://doi.org/10.3389/fpls.2020. 555376

Bentivegna F, Ciampa M, Mazza G, Paglialonga A, Travaglini A (2003) Loggerhead turtle (Caretta caretta) in Tyrrhenian sea: trophic role of the Gulf of Naples. In: Margaritoulis D, Demetropolous A (eds) Proceedings of the first Mediterranean conference on marine turtles. Barcelona Convention-Bern Convention-Bonn Convention (CMS), Nicosia, pp 71-75

Bjorndal KA (1997) Foraging ecology and nutrition of sea turtles. In: Lutz PL, Musick A (eds) The biology of sea turtles. CRC Press, Boca Raton

Bjorndal KA, Jackson JBC (2003) Roles of sea turtles in marine ecosystems: reconstructing the past. In: Lutz PL, Musick JA, Wyneken J (eds) Biology of sea turtles, vol II. CRC Press, Boca Raton (ISBN 9780429118296)

Bolten AB (1999) Techniques for measuring sea turtles. In: Eckert KL, Bjorndal KA, Abreu-Grobois F, Donnelly M (eds) Research and management techniques for the conservation of sea turtles. 
IUCN/SSC Marine Turtle Specialist Group, Washington (ISBN 2831703646)

Boutard M, Cerisy T, Nogue P-Y, Alberti A, Weissenbach J, Salanoubat M, Tolonen AC (2014) Functional diversity of carbohydrateactive enzymes enabling a bacterium to ferment plant biomass. PLoS Genet 10:e1004773. https://doi.org/10.1371/journal.pgen. 1004773

Bowen WD, Iverson SJ (2013) Methods of estimating marine mammal diets: a review of validation experiments and sources of bias and uncertainty. Mar Mamm Sci 29:719-754. https://doi.org/10. 1111/j.1748-7692.2012.00604.x

Broderick AC, Glen F, Godley BJ, Hays GC (2002) Estimating the number of green and loggerhead turtles nesting annually in the Mediterranean. Oryx 36:227-235. https://doi.org/10.1017/S0030 605302000431

Burke VJ, Morreale SJ, Standora EA (1994) Diet of the Kemps ridley sea turtle, Lepidochelys kempii, in New York waters. Fish Bull 92:26-32

Campos P, Cardona L (2020) Trade-offs between nutritional quality and abundance determine diet selection in juvenile benthic green turtles. J Exp Mar Biol Ecol 527:151373. https://doi.org/ 10.1016/j.jembe.2020.151373

Campos P, Guivernau M, Prenafeta-Boldú FX, Cardona L (2018) Fast acquisition of a polysaccharide fermenting gut microbiome by juvenile green turtles Chelonia mydas after settlement in coastal habitats. Microbiome 6:69. https://doi.org/10.1186/ s40168-018-0454-z

Cardona L, Campos P, Levy Y, Demetropoulos A, Margaritoulis D (2010) Asynchrony between dietary and nutritional shifts during the ontogeny of green turtles (Chelonia mydas) in the Mediterranean. J Exp Mar Biol Ecol 393:83-89. https://doi.org/10.1016/j. jembe.2010.07.004

Carrión-Cortez JA, Zárate P, Seminoff JA (2010) Feeding ecology of the green sea turtle (Chelonia mydas) in the Galapagos Islands. J Mar Biol Assoc UK 90:1005-1013. https://doi.org/10.1017/ S0025315410000226

Casale P (2011) Sea turtle by-catch in the Mediterranean. Fish Fish 12:299-316. https://doi.org/10.1111/j.1467-2979.2010.00394.x

Casale P, Freggi D, Basso R, Argano R (2005) Size at male maturity, sexing methods and adult sex ratio in loggerhead turtles (Caretta caretta) from Italian Waters Investigated Through Tail Measurements. Herpetol J 15:145-148. http://hdl.handle.net/11568/ 825506

Casale P, Freggi D, Basso R, Vallini C, Argano R (2007) A model of area fidelity, nomadism, and distribution patterns of loggerhead sea turtles (Caretta caretta) in the Mediterranean Sea. Mar Biol 152:1039-1049. https://doi.org/10.1007/s00227-007-0752-7

Casale P, Abbate G, Freggi D, Conte N, Oliverio M, Argano R (2008) Foraging ecology of loggerhead sea turtles Caretta caretta in the central Mediterranean Sea: evidence for a relaxed life history model. Mar Ecol Prog Ser 372:265-276. https://doi.org/10. 3354/meps07702

Casale P, Broderick AC, Camiñas JA, Cardona L, Carreras C, Demetropoulos A, Fuller WJ, Godley BJ, Hochscheid S, Kaska Y, Lazar B, Margaritoulis D, Panagopoulou A, Rees AF, Tomás J, Türkozan O (2018) Mediterranean sea turtles: current knowledge and priorities for conservation and research. Endang Species Res 36:229-267. https://doi.org/10.3354/esr00901

Christianen MJA, Herman PMJ, Bouma TJ, Lamers LPM, van Katwijk MM, van der Heide T, Mumby PJ, Silliman BR, Engelhard SL, van de Kerk M, Kiswara W, van de Koppel J (2014) Habitat collapse due to overgrazing threatens turtle conservation in marine protected areas. Proc R Soc B 281:20132890. https://doi.org/10. 1098/rspb.2013.2890
Christianen MJA, Smulders FOH, Engel MS, Nava MI, Willis S, Debrot AO, Palsbøll PJ, Vonk JA, Becking LE (2018) Megaherbivores may impact expansion of invasive seagrass in the Caribbean. J Ecol 107:45-57. https://doi.org/10.1111/1365-2745. 13021

Clukey KE, Lepczyk CA, Balazs GH, Work TM, Lynch JM (2017) Investigation of plastic debris ingestion by four species of sea turtles collected as bycatch in pelagic Pacific longline fisheries. Mar Pollut Bull 120:117-125. https://doi.org/10.1016/j.marpo lbul.2017.04.064

Clusa M, Carreras C, Pascual M, Gaughran SJ, Piovano S, Giacoma C, Fernández G, Levy Y, Tomás J, Raga JA, Maffucci F, Hochscheid S, Aguilar A, Cardona L (2014) Fine-scale distribution of juvenile Atlantic and Mediterranean loggerhead turtles (Caretta caretta) in the Mediterranean Sea. Mar Biol 161:509-519. https://doi.org/10.1007/s00227-013-2353-y

Corsini-Foka M, Kondylatos G, Santorinios E (2013) Increase of sea turtles stranding records in Rhodes Island (eastern Mediterranean Sea): update of a long-term survey. J Mar Biol Assoc UK93:1991-2002. https://doi.org/10.1017/S0025315413000556

Demetropoulos A, Hadjichristophorou M (1995) Manual on marine turtle conservation in the Mediterranean. UNEP(MAP/SPA)/ IUCN/CWS/Fisheries Department. MANRE, Cyprus, $\mathrm{p} 73$

Demir M (2003) Shells of mollusca collected from the seas of Turkey. Turk Zool Derg 27:101-140

Di Beneditto APM, Awabdi DR (2014) How marine debris ingestion differs among megafauna species in a tropical coastal area. Mar Pollut Bull 88:86-90. https://doi.org/10.1016/j.marpolbul.2014. 09.020

Di Camillo CG, Coppari M, Bartolucci I, Bo M, Betti F, Bertolino M, Calcinai B, Cerrano C, De Grandis G, Bavestrello G (2011) Temporal variations in growth and reproduction of Tedania anhelans and Chondrosia reniformis in the North Adriatic Sea. In: Maldonado M, Turon X, Becerro M, Jesús Uriz M (eds) Ancient animals, new challenges. Developments in hydrobiology, vol 219. Springer, Dordrecht, pp 299-313. https://doi.org/10.1007/ 978-94-007-4688-6_25

Duncan EM, Arrowsmith JA, Bain CE, Bowdery H, Broderick AC, Chalmers T, Fuller WJ, Galloway TS, Lee JH, Lindeque PK, Omeyer LCM, Snape RTE, Godley BJ (2019) Diet-related selectivity of macroplastic ingestion in green turtles (Chelonia mydas) in the eastern Mediterranean. Sci Rep 9:11581. https://doi.org/ 10.1038/s41598-019-48086-4

Durmuş SH (1998) An investigation on biology and ecology of the sea turtle population on Kazanlı and Samandağ Beaches. Dokuz Eylül University, Graduate School of Natural and Applied Sciences. PhD. Thesis.

Esteban N, Mortimer JA, Stokes HJ, Laloë J-O, Unsworth RK, Hays GC (2020) A global review of green turtle diet: sea surface temperature as a potential driver of omnivory levels. Mar Biol 167:1-17. https://doi.org/10.1007/s00227-020-03786-8

Flint P (2019) Observation of Odonata from northern Cyprus. Libellula 38:1-28

Gambi MC, Barbieri F, Bianchi CN (2009) New record of the alien seagrass Halophila stipulacea (Hydrocharitaceae) in the western Mediterranean: a further clue to changing Mediterranean Sea biogeography. Mar Biodivers Rec 2:e84. https://doi.org/10.1017/ S175526720900058X

Georgiou D, Alexandre A, Luis J, Santos R (2016) Temperature is not a limiting factor for the expansion of Halophila stipulacea throughout the Mediterranean Sea. Mar Ecol Prog Ser 544:159167. https://doi.org/10.3354/meps11582

Gillis AJ, Ceriani SA, Seminoff JA, Fuentes MM (2018) Foraging ecology and diet selection of juvenile green turtles in the Bahamas: 
insights from stable isotope analysis and prey mapping. Mar Ecol Prog Ser 599:225-238. https://doi.org/10.3354/meps12635

Godley BJ, Smith SM, Clark PF, Taylor JD (1997) Molluscan and crustacean items in the diet of the loggerhead turtle, Caretta caretta (Linnaeus, 1758) [Testudines: Chelonidae] in the eastern Mediterranean. J Molluscan Stud 63:474-476. https://doi.org/10. 1093/mollus/63.3.474

Godley BJ, Thompson DR, Waldron S, Furness RW (1998) The trophic status of marine turtles a determined by stable isotope analysis. Mar Ecol Prog Ser 166:277-284. https://doi.org/10.3354/meps1 66277

Green DB, Bestley S, Trebilco R, Corney SP, Lehodey P, McMahon CR, Guinet C, Hindell MA (2020) Modelled mid-trophic pelagic prey fields improve understanding of marine predator foraging behaviour. Ecography 43:1014-1026. https://doi.org/10.1111/ ecog.04939

Hamabata T, Hikida T, Okamoto K, Watanabe S, Kamezaki N (2015) Ontogenetic habitat shifts of green turtles (Chelonia mydas) suggested by the size modality in foraging aggregations along the coasts of the western Japanese main islands. J Exp Mar Biol Ecol 463:181-188. https://doi.org/10.1016/j.jembe.2014.12.007

Haug T, Falk-Petersen S, Greenacre M, Hop H, Lindstrøm U, Meier S, Nilssen KT, Wold A (2017) Trophic level and fatty acids in harp seals compared with common minke whales in the Barents Sea. Mar Biol 13:919-932. https://doi.org/10.1080/17451000. 2017.1313988

Haywood JC, Fuller WJ, Godley BJ, Shutler JD, Stephen Widdicombe S, Broderick AC (2019) Global review and inventory: how stable isotopes are helping us understand ecology and inform conservation of marine turtles. Mar Ecol Prog Ser 613:217-245. https:// doi.org/10.3354/meps 12889

Haywood JC, Casale P, Freggi D, Fuller WJ, Godley BJ, Lazar B, Margaritoulis D, Rees AF, Shutler JD, Snape RT, Swain-Diaz NR, Widdicombe S, Broderick AC (2020a) Foraging ecology of Mediterranean juvenile loggerhead turtles: insights from $\mathrm{C}$ and $\mathrm{N}$ stable isotope ratios. Mar Biol 167:28. https://doi.org/10.1007/ s00227-020-3647-5

Haywood JC, Fuller WJ, Godley BJ, Margaritoulis D, Shuter JD, Snape RTE, Widdicombe S, Zbinden JA, Broderick AC (2020b) Spatial ecology of loggerhead turtles: Insights from stable isotope markers and satellite telemetry. Divers Distrib 26:368-381. https://doi. org/10.1111/ddi.13023

Howell LN, Reich KJ, Shaver DJ, Landry AM Jr, Gorga CC (2016) Ontogenetic shifts in diet and habitat of juvenile green sea turtles in the northwestern Gulf of Mexico. Mar Ecol Prog Ser 559:217229. https://doi.org/10.3354/meps11897

INDICIT Consortium (2018) Monitoring marine litter impacts on sea turtles. Protocol for the collection of data on ingestion and entanglement in the loggerhead turtle (Caretta caretta Linnaeus, 1758). European Commission. https://indicit-europa.eu/cms/ wpcontent/uploads/2018/09/Protocole_v7_hd.pdf. Accessed 6 June 2020

John E, Sparrow DJ, Sparrow RL (2015) Migration of Lepidoptera in the vicinity of Cyprus, eastern Mediterranean, April 2014. Entomol Gaz 66:255-262

Jordà G, Marbà N, Duarte CM (2012) Mediterranean seagrass vulnerable to regional climate warming. Nat Clim Change 2:821-824. https://doi.org/10.1038/nclimate1533

Karaa S, Bradai MN, Jribi I, Bouain A (2012) The occurrence of the green sea turtle Chelonia mydas, in the Gulf of Gabes (Tunisia). Vie Milieu 62:1-6

Katsanevakis S, Wallentinus I, Zenetos A, Leppäkoski E, Çinar ME, Oztürk B, Grabowski M, Golani D, Cardoso AC (2014) Impacts of invasive alien marine species on ecosystem services and biodiversity: a pan-European review. Aquat Invasions 9:391-423. https://doi.org/10.3391/ai.2014.9.4.01
Komoroske LM, Jensen MP, Stewart KR, Shamblin BM, Dutton PH (2017) Advances in the application of genetics in marine turtle biology and conservation. Front Mar Sci 4:156. https://doi.org/ 10.3389/fmars.2017.00156

Laurent L, Lescure J (1994) L'hivernage des tortues caouannes Caretta caretta (L.) dans le sud Tunisien. Rev Ecol 49:63-86. http://hdl. handle.net/2042/54750

Lazar B, Zavodnik D, Grbac I, Tvrtkovic N (2002) Diet composition of the loggerhead sea turtle Caretta caretta in the northern Adriatic Sea: a preliminary study. In: Mosier A, Foley A, Brost B (eds) Proc 20th annu symp on sea turtle biology and conservation. NOAA Tech Memo NMFSSEFSC-477, pp 146-147

Lazar B, Gracan R, Zavodnik D, Tvrtkovic N (2007) Feeding ecology of "pelagic" loggerhead turtles, Caretta caretta, in the northern Adriatic Sea: proof of an early ontogenetic habitat shift. Proceedings of the 25th Annual Symposium on Sea Turtle Biology and Conservation. NOAA

Lazar B, Gračan R, Zavodnik D, Tvrtković N (2008a) Feeding ecology of "pelagic" loggerhead turtles, Caretta caretta, in the northern Adriatic Sea: proof of an early ontogenetic habitat shift. In: Kalb H, Rohde AS, Gayheart K, Shanker K (eds) Proceedings of the twenty-fifth symposium on sea turtle biology and conservation. NOAA/NMFS, Miami, pp 93-93

Lazar B, Lacković G, Casale P, Freggi D, Tvrtković N (2008b) Histological validation of gonad gross morphology to sex juvenile loggerhead sea turtles (Caretta caretta). Herpetol J 18:137-140

Lazar B, Žuljević A, Holcer D (2010) Diet composition of a green turtle, Chelonia mydas, from the Adriatic Sea. Nat Croat 19:263-271

Lewison RL, Crowder LB, Wallace BP, Moore JE, Cox T, Zydelis R, McDonald S, Di Matteo A, Dunn DC, Kot CY, Bjorkland R (2014) Global patterns of marine mammal, seabird, and sea turtle bycatch reveal taxa-specifc and cumulative megafauna hotspots. Proc Natl Acad Sci USA 111:5271-5276. https://doi.org/10. 1073/pnas.1318960111

Lipkin Y (1975) Halophila stipulacea in cyprus and rhodes, 19671970. Aqua Bot 1:309-320. https://doi.org/10.1016/03043770(75)90029-7

Marco-Méndez C, Ferrero-Vicente LM, Prado P, Heck KL, Cebrián J, Sánchez-Lizaso JL (2015) Epiphyte presence and seagrass species identity influence rates of herbivory in Mediterranean seagrass meadows. Estuar Coast Shelf Sci 154:94-101. https:// doi.org/10.1016/j.ecss.2014.12.043

Margaritoulis D, Teneketzis K (2003) Identification of a developmental habitat of the green turtle in Lakonikos Bay, Greece. In: Margaritoulis A, Demetropoulos A (eds) Proceedings of the First Mediterranean Conference on Marine Turtles. Barcelona Convention-Bern Convention-Bonn Convention (CMS), Nicosia, pp 170-175

Marshall CD, Guzman A, Narazaki T, Sato K, Kane EA, Sterba-Boatwright BD (2012) The ontogenetic scaling of bite force and head size in loggerhead sea turtles (Caretta caretta): implications for durophagy in neritic, benthic habitats. J Exp Biol 215:41664174. https://doi.org/10.1242/jeb.074385

Matiddi M, Hochscheid S, Camedda A, Baini M, Cocumelli C, Serena F, Tomassetti P, Travaglini A, Marra S, Campani T, Scholl F, Mancusi C, Amato E, Briguglio P, Maffucci F, Fossi MC, Bentivegna F, de Lucia GA (2017) Loggerhead sea turtle (Caretta caretta): a target species for monitoring litter ingested by marine organisms in the Mediterranean Sea. Environ Pollut 230:199_ 209. https://doi.org/10.1016/j.envpol.2017.06.054

Mazaris AD, Schofield G, Gkazinou C, Almpanidou V, Hays GC (2017) Global sea turtle conservation successes. Sci Adv 3:e1600730. https://doi.org/10.1126/sciadv.1600730

McDermid KJ, Jha R, Rice MR, Balazs GH (2018) Of turtles and trees: nutritional analysis of tree heliotrope (Heliotropium 
foertherianum) leaves consumed by green turtles (Chelonia mydas) in Hawai' 1 . Micronesica 2018-02:1-11

Meylan A (1988) Spongivory in Hawksbill turtles: a diet of glass. Science 239:393-395. https://doi.org/10.1126/science.239.4838.393

Musick JA, Limpus CJ (1997) Habitat utilization and migration in juvenile sea turtles. In: Lutz PL, Musick JA (eds) The biology of sea turtles. CRC Press, Boca Raton, Florida, pp 137-163

Newsome SD, Clementz MT, Koch PL (2010) Using stable isotope biogeochemistry to study marine mammal ecology. Mar Mamm Sci 26:509-572. https://doi.org/10.1111/j.1748-7692.2009.00354.x

Nguyen HM, Kleitou P, Kletou D, Sapir Y, Winters G (2018) Differences in flowering sex ratios between native and invasive populations of the seagrass Halophila stipulacea. Bot Mar 61:337-342. https://doi.org/10.1515/bot-2018-0015

Nguyen HM, Savva I, Kleitou P, Kletou D, Lima FP, Sapir Y, Winters G (2020) Seasonal dynamics of native and invasive $\mathrm{Hal}$ ophila stipulacea populations-a case study from the northern Gulf of Aqaba and the eastern Mediterranean Sea. Aquat Bot 162:103205. https://doi.org/10.1016/j.aquabot.2020.103205

Özdilek ŞYS, Aureggi M (2006) Strandings of juvenile green turtles at Samandağ, Turkey. Chelonian Conserv Biol 5:152-154. https:// doi.org/10.2744/1071-8443(2006)5[152:SOJGTA]2.0.CO;2

Özdilek ŞY, Akdeniz B, Firat AR, Balkan EI, Gürsoy S, Sönmez B, Erduğan H (2015) Green turtles (Chelonia mydas) feeding on invasive algae Caulerpa taxifolia in Turkey. Russ J Herpetol 22:139-142

Parker DM, Dutton PH, Balazs GH (2011) Oceanic diet and distribution of haplotypes for the green turtle, Chelonia mydas, in the central North Pacific. Pac Sci 65:419-431. https://doi.org/10. 2984/65.4.419

R Core Team (2020) R: a language and environment for statistical computing. R Foundation for Statistical Computing, Vienna, Austria. https://www.R-project.org/. Accessed 29 October 2020

Reich KJ, Bjorndal KA, Bolten AB (2007) The 'lost years' of green turtles: using stable isotopes to study cryptic lifestages. Biol Lett 3:712-714. https://doi.org/10.1098/rsbl.2007.0394

Reisser J, ProiettiIvan M, Sazima I, Kinas P, Horta P, Secchi E (2013) Feeding ecology of the green turtle (Chelonia mydas) at rocky reefs in western South Atlantic. Mar Biol 160:3169-3179. https://doi.org/10.1007/s00227-013-2304-7

Richardson JI, McGillivary P (1991) Post-hatchling loggerhead turtles eat insects in Sargassum community. Mar Turt News1 55:2-5

Rizzi M, Rodrigues FL, Medeiros L, Ortega I, Rodrigues L, Monteiro DS, Kessler F, Proietti MC (2019) Ingestion of plastic marine litter by sea turtles in southern Brazil: abundance, characteristics and potential selectivity. Mar Pollut Bull 140:536-548. https:// doi.org/10.1016/j.marpolbul.2019.01.054

Salmon M, Jones TT, Horch KW (2004) Ontogeny of diving and feeding behavior in juvenile seaturtles: leatherback seaturtles (Dermochelys coriacea $\mathrm{L}$ ) and green seaturtles (Chelonia mydas $\mathrm{L}$ ) in the Florida Current. J Herpetol 38:36-44. https://doi.org/10. $1670 / 228-01 \mathrm{~A}$

Schuyler Q, Hardesty BD, Wilcox C, Townsend K (2013) Global analysis of anthropogenic debris ingestion by sea turtles. Conserv Biol 28:129-139. https://doi.org/10.1111/cobi.12126

Schwarz D, Spitzer SM, Thomas AC, Kohnert CM, Keates TR, Acevedo-Gutiérrez A (2018) Large-scale molecular diet analysis in a generalist marine mammal reveals male preference for prey of conservation concern. Ecol Evol 8:9889-9905. https://doi.org/ 10.1002/ece 3.4474

Sghaier YR, Zakhama-Sraieb R, Charfi-Cheikhrouha F (2014) Effects of the invasive seagrass Halophila stipulacea on the native seagrass Cymodocea nodosa. Proceedings of the fifth Mediterranean symposium on marine vegetation. UNEP, Portorož, Slovenia, pp 167-171
Shiffler RE (1988) Maximum Z scores and outliers. Am Stat 42:79-80. https://doi.org/10.1080/00031305.1988.10475530

Smulders FEH, Vonk JA, Engel MS, Christianen MJA (2017) Expansion and fragment settlement of the non-native seagrass Halophila stipulacea in a Caribbean bay. Mar Biol Res 13:967-974. https://doi.org/10.1080/17451000.2017.1333620

Snape RTE, Beton D, Broderick AC, Çiçek BA, Fuller WJ, Özden O, Godley BJ (2013) Strand monitoring and anthropological surveys provide insight into marine turtle bycatch in small-scale fisheries of the Eastern Mediterranean. Chelonian Conserv Biol 12:44-55. https://doi.org/10.2744/CCB-1008.1

Spalding M, Taylor M, Ravilious C, Short F, Green E (2003) Global overview: the distribution and status of seagrasses. In: Green EP, Short FT (eds) World Atlas of Seagrasses. Prepared by the UNEP World Conservation Monitoring Centre. University of California Press, Berkeley, USA, pp 5-26

Sparrow DJ, Sparrow R, De Knijf G (2016) Odonata. In: Sparrow DJ, John E (eds) An introduction to the wildlife of Cyprus. Terra Cypria, pp 65-132

Steuer A (1905) Uber das Kiemenfilter und die Nahrung adriatischer Fische. Verb. K.K. Zoo Bot Ges Wien 55:275-299

Stokes KL, Fuller WJ, Glen F, Godley BJ, Hodgson DJ, Rhodes KA, Snape RTE, Broderick AC (2014) Detecting green shoots of recovery: the importance of long-term individual-based monitoring of marine turtles. Anim Conserv 17:593-602. https://doi. org/10.1111/acv.12128

Stokes KL, Broderick AC, Canbolat AF, Candan O, Fuller WJ, Glen F, Levy Y, Rees AF, Rilov G, Snape RT, Stott I, Tchernov D, Godley BJ (2015) Migratory corridors and foraging hotspots: critical habitats identified for Mediterranean green turtles. Divers Distrib 21:665-674. https://doi.org/10.1111/ddi.12317

Stokes HJ, Mortimer JA, Hays GC, Unsworth RKF, Laloë J-O, Esteban N (2019) Green turtle diet is dominated by seagrass in the Western Indian Ocean except amongst gravid females. Mar Biol 166:135. https://doi.org/10.1007/s00227-019-3584-3

Stringell TB, Calosso MC, Claydon JAB, Clerveau W, Godley BJ, Lockhart KJ, Phillips Q, Ranger S, Richardson PB, Sangherad A, Broderick AC (2013) Marine turtle harvest in a mixed smallscale fishery: evidence for revised management measures. Ocean Coast Manag 82:34-42. https://doi.org/10.1016/j.ocecoaman. 2013.05.004

Stringell TB, Clerveaux WV, Godley BJ, Kent FEA, Lewis EDG, Marsh JE, Phillips Q, Richardson PB, Sanghera A, Broderick AC (2016) Taxonomic distinctness in the diet of two sympatric marine turtle species. Mar Ecol 37:1036-1049. https://doi.org/ 10.1111/maec. 12349

Telesca L, Belluscio A, Criscoli A, Ardizzone G, Apostolaki ET, Fraschetti S, Gristina M, Knittweis L, Martin CS, Pergent G, Alagna A, Badalamenti F, Garofalo G, Gerakaris V, Pace ML, Pergent-Martini C, Salomidi M (2015) Seagrass meadows (Posidonia oceanica) distribution and trajectories of change. Sci Rep 5:12505. https://doi.org/10.1038/srep12505

Teneketzis K, Antonopolou M, Koutsoubas D, Margaritoulis D (2006) Confirmation of a green turtle developmental habitat in Lakonikos bay, southern Greece, through stomach content analysis. Book of abstracts of the 10th international congress on the zoogeography and ecology of Greece and adjacent regions. The Hellenic Zoological Society, Greece, p 210

Thomson JA, Whitman ER, Garcia-Rojas MI, Bellgrove A, Ekins M, Hays GC, Heithaus MR (2018) Individual specialization in a migratory grazer refects long-term diet selectivity on a foraging ground: implications for isotope-based tracking. Oecologia 188:429-439. https://doi.org/10.1007/s00442-018-4218-z

Tikochinski Y, Bradshaw P, Mastrogiacomo A, Broderick A, Daya A, Demetropoulos A, Demetropoulos S, Eliades N-G, Fuller W, Godley B, Kaska Y, Levy Y, Snape R, Wright L, Carreras C 
(2018) Mitochondrial DNA short tandem repeats unveil hidden population structuring and migration routes of an endangered marine turtle. Aquat Conserv 28:788-797. https://doi.org/10. 1002/aqc. 2908

Tomás J, Aznar FJ, Raga JA (2001) Feeding ecology of the loggerhead turtle Caretta caretta in the western Mediterranean. J Zool 255:525-532. https://doi.org/10.1017/S0952836901001613

Türkozan O, Yılmaz C, Uçar AH, Carreras C, Ergene S, Aymak C, Karaman S (2018) Local differentiation in the origin of stranded loggerhead turtles, Caretta caretta, within an eastern Turkey foraging area. Ocean Coast Manag 153:70-75. https://doi.org/10. 1016/j.ocecoaman.2017.12.011

Vander Zanden HB, Bjorndal KA, Reich KJ, Bolten AB (2010) Individual specialists in a generalist population: results from a longterm stable isotope series. Biol Lett 6:711-714. https://doi. org/10.1098/rsbl.2010.0124

Vélez-Rubio GM, Cardona L, López-Mendilaharsu M, Souza GM, Carranza A, González-Paredes D, Tomás J (2016) Ontogenetic dietary changes of green turtles (Chelonia mydas) in the temperate southwestern Atlantic. Mar Biol 163:57. https://doi.org/10. 1007/s00227-016-2827-9

Violle C, Enquist BJ, McGill BJ, Jiang LIN, Albert CH, Hulshof C, Jung V, Messier J (2012) The return of the variance: intraspecific variability in community ecology. Trends Ecol Evol 27:244-252. https://doi.org/10.1016/j.tree.2011.11.014

von Brandis RG, Mortimer JA, Reilly BK, van Soest RWM, Branch GM (2014) Diet composition of hawksbill turtles (Eretmochelys imbricata) in the Republic of Seychelles. West Indian Ocean J Mar Sci 13:81-91

Wallace BP, Heppell SS, Lewison RL, Kelez S, Crowder LB (2008) Impacts of fisheries bycatch on loggerhead turtles worldwide inferred from reproductive value analyses. J Appl Ecol 45:10761085. https://doi.org/10.1111/j.1365-2664.2008.01507.x

Wallace BP, DiMatteo AD, Bolten AB, Chaloupka MY, Hutchinson BJ, Abreu-Grobois FA, Mortimer JA, Seminoff JA, Amorocho D, Bjorndal KA, Bourjea J, Bowen BW, Dueñas RB, Casale P, Choudhury BC, Costa A, Dutton PH, Fallabrino A, Finkbeiner EM, Girard A, Girondot M, Hamann M, Hurley BJ, LópezMendilaharsu M, Marcovaldi MA, Musick JA, Nel R, Pilcher NJ,
Troëng S, Witherington B, Mast RB (2011) Global conservation priorities for marine turtles. PLoS ONE 6:e24510. https://doi. org/10.1371/journal.pone.0024510

Whitman ER, Heithaus MR, Barcia LG, Brito DN, Rinaldi C, Kiszka JJ (2019) Effect of seagrass nutrient content and relative abundance on the foraging behavior of green turtles in the face of a marine plant invasion. Mar Ecol Prog Ser 628:171-182. https://doi.org/ 10.3354/meps13092

Wildermann NE, Gredzens C, Avens L, Barrios-Garrido HA, Bell I, Blumenthal J, Bolten AB, McNeill JB, Casale P, Di Domenico M, Domit C (2018) Informing research priorities for immature sea turtles through expert elicitation. Endanger Species Res 37:55-76. https://doi.org/10.3354/esr00916

Willette DA, Ambrose RF (2012) Effects of the invasive seagrass Halophila stipulacea on the native seagrass, Syringodium filiforme, and associated fish and epibiota communities in the Eastern Caribbean. Aquat Bot 103:74-82. https://doi.org/10.1016/j.aquabot. 2012.06.007

Winters G, Beer S, Willette DA, Viana IG, Chiquillo KL, Beca-Carretero P, Villamayor B, Azcárate-García T, Shem-Tov R, Mwabvu B, Migliore L, Rotini A, Oscar MA, Belmaker J, Gamliel I, Alexandre A, Engelen AH, Procaccini G, Rilov G (2020) The tropical Seagrass Halophila stipulacea: reviewing what we know from its native and invasive habitats, alongside identifying knowledge gaps. Front Mar Sci 7:300. https://doi.org/10.3389/fmars.2020. 00300

Witherington BE (2002) Ecology of neonate loggerhead turtles inhabiting lines of downwelling near a Gulf Stream front. Mar Biol 140:843-853. https://doi.org/10.1007/s00227-001-0737-x

Witherington B, Hirama S, Hardy R (2012) Young sea turtles of the pelagic Sargassum-dominated drift community: habitat use, population density, and threats. Mar Ecol Prog Ser 463:1-22. https://doi.org/10.3354/meps09970

Publisher's Note Springer Nature remains neutral with regard to jurisdictional claims in published maps and institutional affiliations. 